\title{
Three different downstream fates of the boreal-summer MJOs on their passages over the Maritime Continent
}

\author{
Joshua-Xiouhua Fu ${ }^{1,2,4} \oplus$ - Wanqiu Wang ${ }^{3} \cdot$ Hong-Li Ren ${ }^{4} \cdot$ Xiaolong Jia $^{4} \cdot$ \\ Toshiaki Shinoda ${ }^{5}$
}

Received: 29 June 2016 / Accepted: 20 October 2017 / Published online: 9 November 2017

(c) The Author(s) 2017. This article is an open access publication

\begin{abstract}
The boreal-summer MJOs exhibit three distinctive downstream evolutions on their passages over the Maritime Continent (MC): (i) smoothly transitioning from Indian Ocean (IO) to western Pacific (type-I); (ii) rapidly decayed over the MC (type-II); and (iii) significantly intensified over the MC (type-III). During the life cycles of type-I and -III MJOs, basin-wide overturning circulations connect the convective dipoles between western and eastern north Pacific. For type-II MJO, regional overturning circulations connect the convective dipoles between the IO and Western North Pacific (WNP). For type-I and -III MJOs, the associated convection over eastern IO is able to generate strong Kevinwave responses and significant positive SST anomalies over the MC and western Pacific. On the other hand, for type-II MJO in the IO, a persistent convection lingers around the WNP. It intensifies westerly monsoon flows, thus preventing the generation of coherent positive SST anomalies ahead of the IO MJO convection. It also blocks the formation of a robust Kelvin-wave response over the MC and western Pacific by delaying the northeastward migrations of the dry
\end{abstract}

Joshua-Xiouhua Fu

xfu@hawaii.edu

1 International Pacific Research Center (IPRC), SOEST, University of Hawaii at Manoa, 1680 East-West Road, POST Bldg. 409D, Honolulu, HI 96822, USA

2 Institute of Atmospheric Sciences, FuDan University, Shanghai, China

3 Climate Prediction Center, NOAA/NWS/NCEP, College Park, MD, USA

4 Laboratory for Climate Studies, National Climate Center, China Meteorological Administration, Beijing, China

5 Texas A\&M University-Corpus Christi, Corpus Christi, TX, USA phase. The convection of type-I and -III MJOs at eastern IO is able to generate positive boundary-layer moisture anomalies along with positive column-integrated moisture tendencies over the MC and western Pacific, thus allowing them to propagate eastward smoothly. On the other hand, the type-II MJO convection in eastern IO is associated with a very dry troposphere and negative column-integrated moisture tendency over western Pacific, which result in the rapid decay of convection over the MC. These results emphasize the important roles of robust Kelvin-wave responses and positive SST anomalies on the eastward propagation of boreal-summer MJOs over the MC through moistening the troposphere ahead of the convection.

Keywords Madden-Julian Oscillation in Boreal Summer $\cdot$ Three distinctive types $\cdot$ Maritime Continent

\section{Introduction}

The Madden-Julian Oscillation (MJO) was discovered more than four decades ago by Madden and Julian (1971, 1972). With very limited observations from sparse tropical islands, amazingly, Madden and Julian were able to depict the essence of the MJO as a year-around global-scale slow eastward-propagating convection-circulation couplet. Around the same time, intra-seasonal oscillation (ISO) was independently found in Asian summer monsoon region (e.g., Krishnamurti and Bhalme 1976; Murakami 1976; Yasunari 1979, 1980). Julian and Madden (1981) postulated that the ISO observed in Asian monsoon region is a portion of the global equatorial oscillation discovered by Madden and Julian $(1971,1972)$.

Using the data collected from the First Global Atmospheric Research Program Global Experiment (FGGE) in 
1979 and the regional Monsoon Experiment (MONEX) during boreal-summer (May-August), Lorenc (1984) and Krishnamurti et al. (1985) showed that an intraseasonal planetary-scale divergent wave (i.e., 200-hPa velocity potential and sea-level-pressure: SLP) traverses around the globe eastward year-around. During boreal summer, the planetaryscale wave appears to modulate the monsoon activity with upper-level divergence (convergence) in association with monsoon active (suppressed) phase. The regional high-resolution MONEX data further revealed that the active (suppressed) monsoon in South Asia results from northwardpropagating trough (ridge) from the equatorial Indian Ocean. Krishnamurti et al. (1988) also documented the coherent intraseasonal fluctuations of sea surface temperature (SST) and surface heat fluxes and suggested the potential importance of air-sea coupling on MJO dynamics and postulated that "a combination of atmospheric internal instabilities and external SST forcing on intra-seasonal time scales may enhance the atmospheric responses towards an eventual satisfactory simulation of intra-seasonal oscillation".

Using 7 years' outgoing longwave radiation (OLR) from 1975 to 1982 , Lau and Chan $(1985,1986)$ showed that the intraseasonal eastward-propagating MJO along the equator appears to be present year-around. The northward-propagating ISO in Asian summer monsoon region arises from the interaction between eastward-propagating MJO and monsoon circulations. Knutson et al. (1986) with 9 years' OLR and 250-mb zonal winds (1975-1983) further confirmed Lau and Chan's findings. Using 6 years' OLR, 850- and 250hPa winds, Knutson and Weickmann (1987) constructed the composite MJO life cycles in boreal-summer (May-October) and boreal winter (November-April), separately. They found that large-scale (wavenumber one) tropical divergent overturning circulations propagate eastward around the globe year-around. The area of upper-level divergence well corresponds to the area of organized convection. During boreal summer, the fluctuations of the ISO convection over Asian summer monsoon and Eastern North Pacific (ENP) regions are strongly modulated by global eastward-propagating MJO. These results tend to support the hypothesis of Julian and Madden (1981) that monsoon ISO might be a regional manifestation of eastward-propagating planetary-scale MJO. Different from boreal winter, the convection body of borealsummer MJO has a dominant northwestward slant structure in Asian-Pacific sector, which is also known as Boreal-Summer Intraseasonal Oscillation (BSISO, Wang and Xie 1997; Lee et al. 2013; Kikuchi et al. 2012; Adames et al. 2016).

On the other hand, Wang and Rui (1990) found that about half of northward-propagating monsoon ISO events over Indian-western Pacific sector have no robust equatorial eastward-propagating components associated, which are called independent northward-propagating ISOs. In addition, northwestward-propagating ISO disturbances are also observed over Asian summer monsoon region (e.g., Murakami 1980; Krishnamurti et al. 1985; Lau and Chan 1986; Wang and Rui 1990; Zhu and Wang 1993). Lawrence and Webster (2002) further examined the relationships between the northward-propagating ISOs and equatorial eastward-propagating MJOs during boreal summer. They found that about 78\% northward-propagating ISOs are associated with an equatorial eastward-propagating MJO, while the remaining $22 \%$ are independent northward-propagating events. This significant percentage reduction of independent northward-propagating events compared to what was found in Wang and Rui (1990) has been attributed to different definitions used in these two studies. Wang and Rui (1990) counted those northward-propagating events with equatorial eastward convective signals weakened over the MC but reintensified over western Pacific as independent northwardpropagating events. A unanswered question remains: what are the major physical processes distinguishing the independent northward-propagating events from those associated with an equatorial eastward-propagating MJO.

Those boreal-summer MJO events that are able to propagate over the MC strongly modulate tropical cyclone activities in the Western North Pacific (WNP), ENP, Gulf of Mexico, and Atlantic Main Development regions (e.g., Liebmann et al. 1994; Maloney and Hartmann 2000; Barrett and Leslie 2009; Klotzbach 2010; Schreck and Molinari 2011; Ventrice et al. 2011), thus offering an excellent predictability source for the extended-range forecasts of tropical cyclone activities in these basins. It is also well-known that present-day weather and climate models still have tremendous difficulties to propagate model MJO through the MC, which has been termed as "MC Prediction Barrier" (MCPB) problem (Vitart et al. 2007; Fu et al. 2013). Therefore, the understanding of those processes that promote or halt Indian Ocean MJO to propagate over the $\mathrm{MC}$ will not only advance our knowledge, but also shed light on the ways to improve model representations of MJO propagations and the extended-range forecasts of downstream impacts of the MJO.

The damping effects of the MC on approaching MJO have long been recognized (Wang and Rui 1990; Nitta et al. 1992), probably through orographic blocking (Inness and Slingo 2006), the suppression of effective air-sea interactions (Zhang and Hendon 1997), and dissipation of moist static energy by rigorous diurnal cycles in association with land-sea and mountain-valley breezes over this region $(\mathrm{Oh}$ et al. 2013). Although the MC poses as a hostile region for eastward-propagating MJOs, many of them survive the MC and propagate into western Pacific (Wang and Rui 1990; Matthews 2008; Kim et al. 2014; Feng et al. 2015). Some even intensify on their passages over the MC (Hirata et al. 2013; Kiladis et al. 2014). The coherent positive SST anomaly (e.g., Krishnamurti et al. 1988; Hirata et al. 2013), orographically-induced PBL convergence (e.g., Hsu and Lee 
Table 1 monthly distributions of three MJO types

\begin{tabular}{lrrrrrrl}
\hline & \multicolumn{1}{c}{ May } & \multicolumn{1}{c}{ June } & \multicolumn{1}{c}{ July } & August & September & October & Total \\
\hline Type-I & $14(6)$ & $10(5)$ & $5(3)$ & $4(3)$ & $8(8)$ & $6(3)$ & $47(28)$ \\
Type-II & $2(1)$ & $3(2)$ & $4(4)$ & $5(2)$ & $3(0)$ & $4(4)$ & $21(13)$ \\
Type-III & $1(0)$ & $2(2)$ & $4(1)$ & $3(3)$ & $3(2)$ & $3(1)$ & $16(9)$ \\
Total & $17(7)$ & $15(9)$ & $13(8)$ & $12(8)$ & $14(10)$ & $13(8)$ & $84(50)$ \\
\hline
\end{tabular}

The numbers outside (in) the brackets are from 21-year OLR (12-year TRMM precipitation)
2005) and preconditioning from a robust dry phase (e.g., Kim et al. 2014) over the MC and western Pacific are viewed as major factors that favor Indian Ocean MJO to propagate into western Pacific.

Almost all previous studies targeting the MJO-MC interactions focus on boreal winter (e.g., Hsu and Lee 2005; Inness and Slingo 2006; Oh et al. 2013; Hirata et al. 2013; Feng et al. 2015) or mix the boreal winter and summer together (e.g., Kim et al. 2014). The boreal-summer MJO-MC interactions remain unknown. Hirata et al. (2013) revealed that during boreal winter there are three distinctive MJO types with different downstream evolutions after reaching the MC: (i), smoothly transitioning into western Pacific; (ii), rapidly decayed over the MC; and (iii), significantly intensified eastward. The present study aims to investigate the boreal-summer MJO-MC interactions by answering following questions: are there three distinctive MJO types in boreal summer as in boreal winter? If so, what are the major features of different MJO types, including their downstream impacts over the ENP and Atlantic basin? What are the major physical processes generating different MJO types? Are there robust precursors for different MJO types?

The remaining part of this article is organized as follows. In Sect. 2, we present the procedure and method used to separate all boreal-summer MJO events into different categories based on their downstream evolutions after reaching the MC. Section 3 explores the precursory signals and diverse downstream impacts of different MJO types as well as documents the physical processes that distinguish each type of the MJOs. Finally, discussions and concluding remarks are given in Sect. 4.

\section{Definition of different MJO types}

The datasets used in this study include 21-year (from 1990 to 2010) NOAA OLR (Liebmann and Smith 1996) and NCEP Climate Forecast System Reanalysis (CFSR, Saha et al. 2010) as well as 12-year (from 1999 to 2010) TRMM precipitation (Huffman et al. 2007) and TMI SST (Wentz et al. 2000). In order to extract intraseasonal signals, three steps are taken. First, we obtain daily anomalies by removing annual cycle and interannual variability. The annual cycle is derived as 21(12)-year means of OLR (TRMM precipitation) for each calendar day and the interannual variability is obtained from 121-day running means of the annual-cycle-removed time series. Second, high-frequency weather is removed by taking 5-day running mean of the resultant time series. Third, Lanczos filter (Duchon 1979) is applied to extract 20-90-day intraseasonal variability.

In order to separate boreal-summer MJOs into different types, we basically follow the procedure used by Hirata et al. (2013). The 21-year intraseasonal OLR anomaly is averaged between $5^{\circ} \mathrm{S}$ and $15^{\circ} \mathrm{N}$, instead of between $5^{\circ} \mathrm{S}$ and $5^{\circ} \mathrm{N}$ used in Hirata et al. (2013) for boreal-winter, to reflect the shift of intra-seasonal convective centers into Northern Hemisphere during boreal summer. Next, EOF analysis is carried out for the equatorially-averaged time series of the filtered OLR anomalies. The first two EOF modes explain more than 50\% of total intra-seasonal variance and are well separated from other higher order modes. The EOF1 manifests as a dipole structure with positive and negative OLR anomalies, respectively, over Indian and western Pacific Oceans, whereas the EOF2 shows a dominant positive OLR anomaly over the MC as in Hirata et al. (2013). Three MJO types are then defined based on the relationships between the EOF1 and EOF2 principal components (PC1, PC2). Type-I represents those events with a minimum PC1 smaller than -1 standard deviation (day 0 for composite) followed by a minimum PC2 smaller than -1 standard deviation within 25 days. Type-II has a minimum PC1 smaller than -1 standard deviation (day 0 for composite) but not the follow-up PC2. Type-III has a minimum PC2 smaller than -1 standard deviation (day 0 for composite) but not the preceding PC1. In a similar fashion, three boreal-summer MJO types are also derived with the 12-year TRMM precipitation.

\section{Physical processes governing three MJO types}

\subsection{Three different MJO types in boreal summer}

With the procedure given in Sect. 2, a total of 84 (50) borealsummer MJO events have been identified from 21-year OLR (12-year TRMM precipitation). Among them, 47 (28) are type-I, 21 (13) are type-II, and remaining 16 (9) are typeIII. The monthly distributions of three MJO types during boreal summer are given in Table 1. Except the type-I MJO 


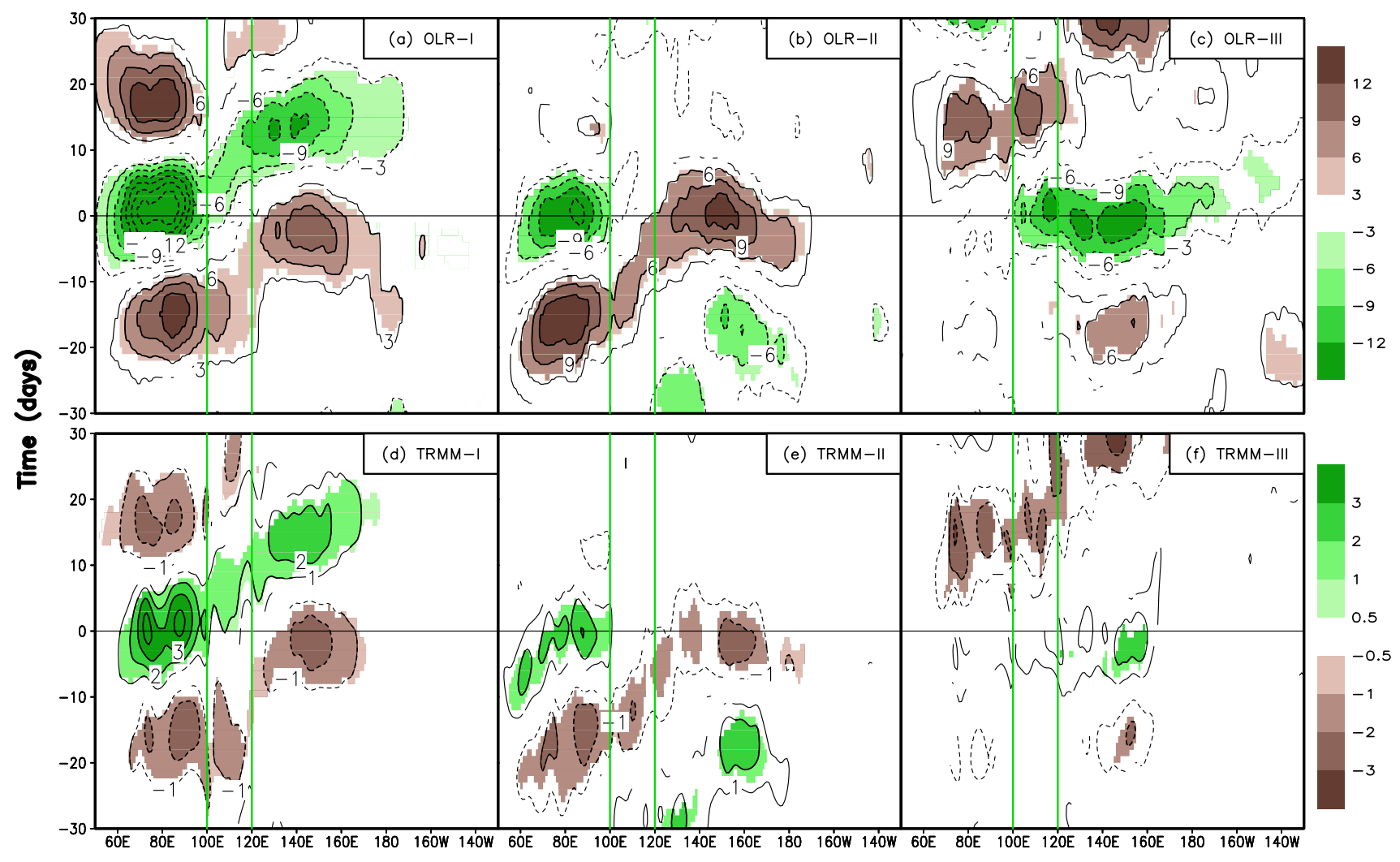

Fig. 1 Composite time-longitude sections of observed OLR (upper panels, CI: $3 \mathrm{~W} \mathrm{~m}^{-2}$ ) and TRMM precipitation (lower-panels, CI: $1 \mathrm{~mm} \mathrm{day}^{-1}$ ) anomalies averaged between $5^{\circ} \mathrm{S}$ and $15^{\circ} \mathrm{N}$ for eastward-propagating MJO events (type-I, a, d), eastward-decaying MJO events (type-II, b, e), and eastward-intensifying MJO events (type-III, c, f). Regions statistically significant above the $5 \%$ level are shaded and drawn with thick contours, whereas with thin contours for areas above the $25 \%$. The two vertical solid lines in green highlight the Maritime Continent from Sumatra islands to Philippine island chains

papers (Kim et al. 2014; Feng et al. 2015). For the type-II (Fig. 1b, e), the MJO convective signal is robust in Indian Ocean, but almost completely dies out once reaching the MC. Our type-II composite is similar to the non-propagating MJO of Kim et al. (2014) and Feng et al. (2015) in terms of the rapid decay of convection over the MC, but also significantly different from them in terms of the dry phase over western Pacific. For our type-II composite, a significant dry phase presents in western Pacific, but not in the composites of Kim et al. (2014) and Feng et al. (2015). The lack of a robust dry phase in western Pacific has been attributed as the key reason for rapid MJO decay over the MC by Kim et al. (2014), whereas Feng et al. (2015) showed that this is not necessarily the case. The differences between our composites and their composites may be due to the different seasons concerned and/or different selection criteria used. The composites of Kim et al. (2014) mixed the cases of winter and summer together, while Feng et al. (2015) only considered very strong cases in winter. For the type-III (Fig. 1c, f), a weak MJO initiates over Indian Ocean, which gains significant strength after crossing the MC and entering western Pacific. It further 


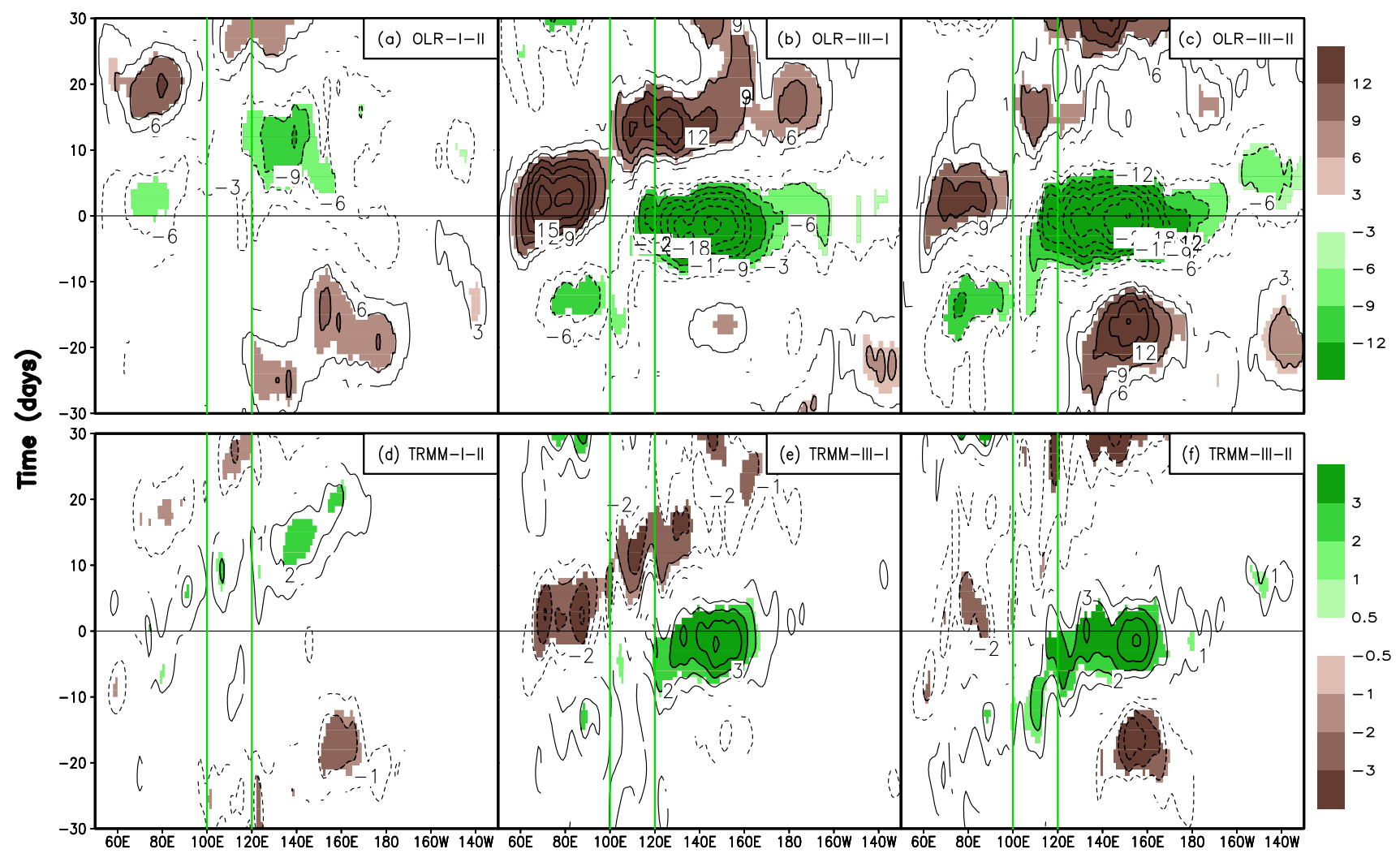

Fig. 2 Differences of composite OLR (upper panels, CI: $3 \mathrm{~W} \mathrm{~m}^{-2}$ ) and TRMM precipitation (lower-panels, CI: $1 \mathrm{~mm} \mathrm{day}^{-1}$ ) anomalies averaged between $5^{\circ} \mathrm{S}$ and $15^{\circ} \mathrm{N}$ between type-I and type-II events (a, d), type-III and type-I events (b, e), and type-III and type-II events

propagates through the Pacific and Atlantic basins and tends to re-initiate in Indian Ocean.

Figure 2 shows the differences among the three-type MJO composites. Compared to type-II, type-I is significantly drier over western Pacific before Indian Ocean convection moving into Pacific (Fig. 2a, d). The convection of type-I is also significantly stronger than that of type-II in particular over western Pacific around +10 days. The type-III is significantly different from both the type-I (Fig. 2b, e) and type-II (Fig. 2c, f) especially the associated convection over western Pacific, which is much stronger than that over Indian Ocean. This result further corroborates that the three different MJO types identified in this study are robust and have distinctive convection features during their passages over the MC.

Four typical examples of each MJO type are given in Fig. 3. For both type-I and type-II MJOs, the eastward-propagating organized convection seems interfered by westwardpropagating dry spells. When the eastward-propagating convection overcomes the westward-propagating dry phase, the eastward-propagating convection prevails (left panels of Fig. 3), thus resulting in a smooth MJO propagation from Indian Ocean to western Pacific. When the eastward convection subdues to the westward dry tendency (in particular (c, f). Regions statistically significant above the 5\% level are shaded and drawn with thick contours, whereas with thin contours for areas above the $25 \%$. The two vertical solid lines in green highlight the Maritime Continent from Sumatra islands to Philippine island chains

Fig. 3e-g), the MJO convective signals rapidly decay over the MC region. The potential role of a westward-propagating dry phase on halting the eastward-propagating MJO has been suggested by Zhu and Wang (1993), Roundy and Frank (2004), and Feng et al. (2015). For type-III MJOs, the convective signals are generally weak and less organized over Indian Ocean, but are significantly intensified after crossing the MC and entering western Pacific.

As mentioned before, most boreal-summer equatorial eastward-propagating MJOs are associated with northwardpropagating monsoon ISOs (e.g., Krishnamurti et al. 1985; Lau and Chan 1986; Knutson et al. 1986; Wang and Rui 1990; Lawrence and Webster 2002). In this study, although our primary focus is to understand the diverse eastwardpropagating boreal-summer MJOs, it is worthwhile to look at the associated northward-propagating ISOs. Figure 4 gives the northward-propagating convective signals in association with three MJO types, respectively, over Indian and western Pacific sectors. For type-I MJO, the associated northward-propagating convection is very robust in both Indian (Fig. 4a, b) and western Pacific (Fig. 4c, d) sectors. While the composite northward-propagating convection over Indian sector is sandwiched between two robust 


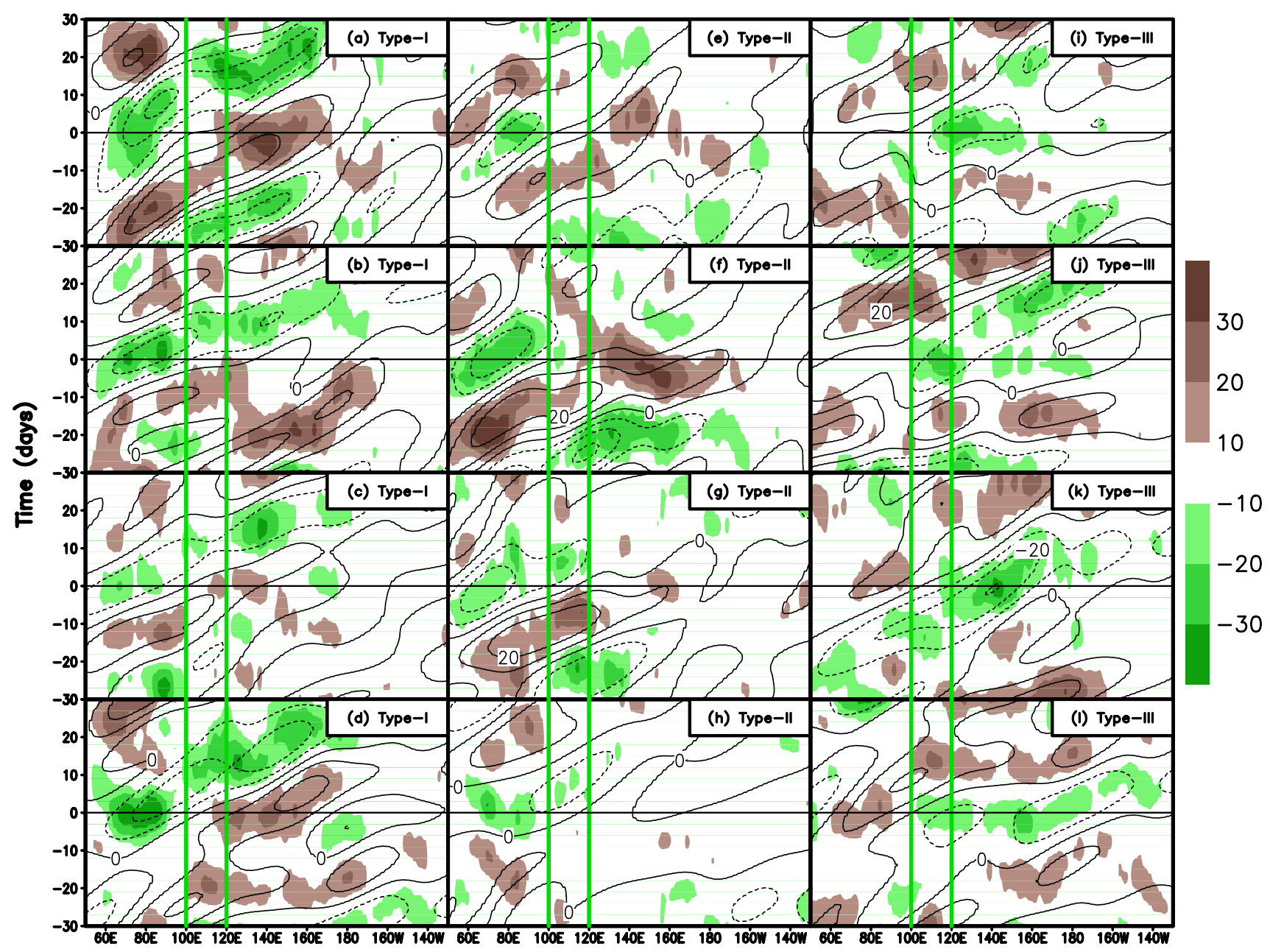

Fig. 3 Time-longitude sections of OLR anomalies (shading) and wavenumber-frequency projected $\mathrm{MJO}$ anomalies (contours, CI: $10 \mathrm{~W} \mathrm{~m}^{-2}$ ) averaged between $5^{\circ} \mathrm{S}$ and $15^{\circ} \mathrm{N}$ for four eastward-propagating MJO events (type-I, a-d), four eastward-decaying MJO events

northward-propagating dry phases (Fig. 4a, b), the dry phase preceding the convection over western Pacific is much stronger than the one after (Fig. 4c, d). For type-II MJO, the associated northward-propagating convection is only robust over Indian sector (Fig. 4e, f), but not over western Pacific (Fig. 4g, h). In this sense, type-II MJO resembles the so-called independent northward-propagating ISOs documented in Wang and Rui (1990) and Lawrence and Webster (2002). The diminished northward-propagating convection over western Pacific (Fig. 4g, h) coincides with an equatorially-trapped dry phase in Indian Ocean (Fig. 4e, f). For typeIII MJO, the northward-propagating convection is weak yet apparent over Indian sector (Fig. 4i, j), followed by a much stronger northward-propagating dry phase and the onset of another wet phase as seen in Fig. 1c, f. Over western Pacific, the corresponding northward-propagating convection is stronger than that over Indian sector (Fig. 4k, 1). The above analysis indicates that the northward-propagating ISOs in
(type-II, e-h), and four eastward-intensifying MJO events (type-III, i-l). The two vertical solid lines in green highlight the Maritime Continent from Sumatra islands to Philippine island chains

both the type-I and type-III (63 cases in total) have apparent eastward-propagating MJOs associated, while the type-II (21 cases) resembles the independent northward-propagating ISOs. This result suggests that about 75\% northward-propagating ISOs are apparently associated with eastward-propagating MJOs while the remaining 25\% resemble the independent northward-propagating ISOs. This partitioning ratio between the independent northward-propagating ISOs and those associated with apparent eastward-propagating MJOs is closer to the finding of Lawrence and Webster (2002) than that of Wang and Rui (1990).

Different MJO types also show different precursory signals and downstream impacts over Western Hemisphere. Figure 5 gives the composite life cycles of 200-hPa velocity potential (VP200 hereafter) and vertical shear of zonal winds (200-850-hPa, U200-U850 hereafter) along with the convection of three $\mathrm{MJO}$ types averaged over $\left(5^{\circ} \mathrm{S}-15^{\circ} \mathrm{N}\right)$. The developments of both type-I and type-II MJO convection in 


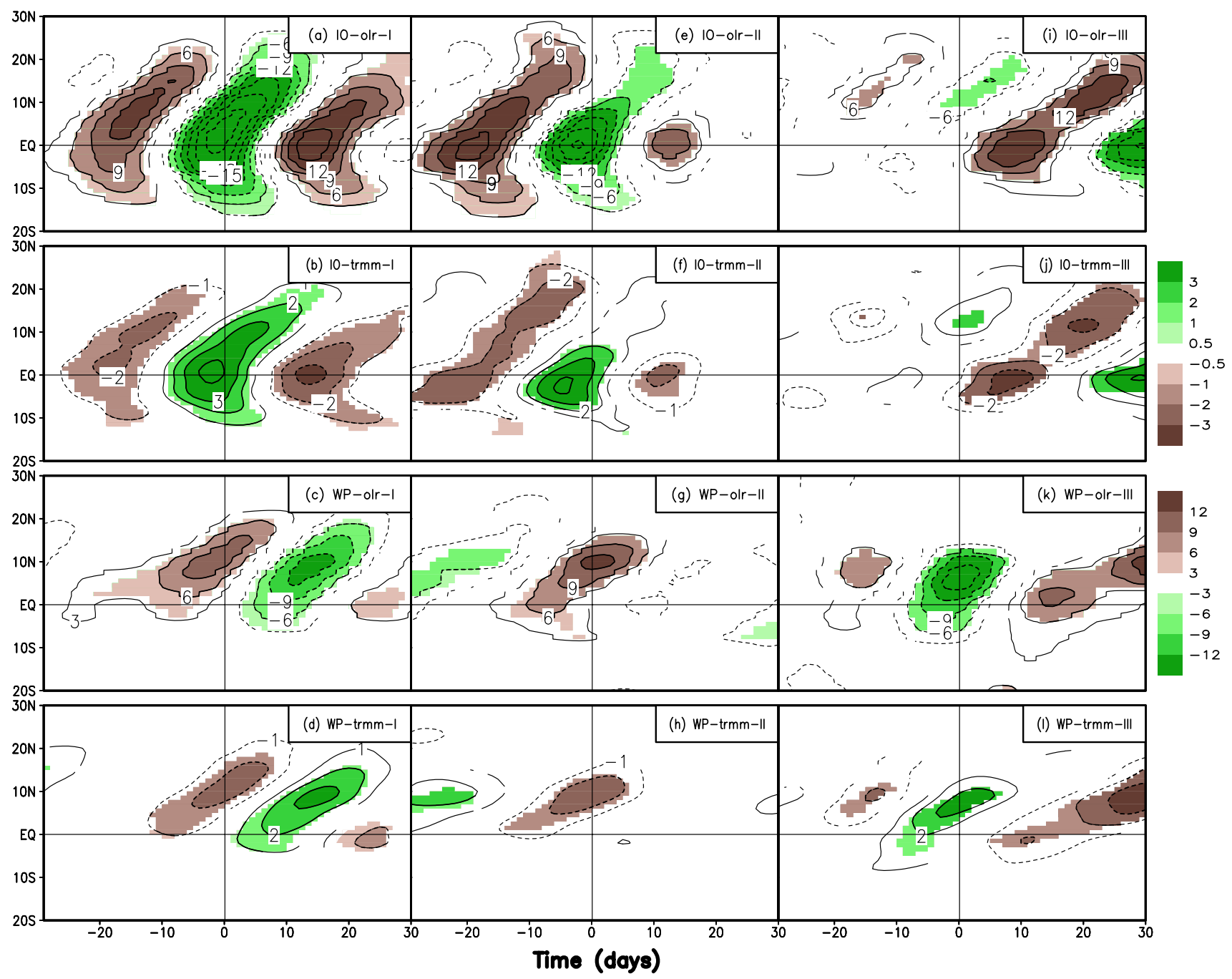

Fig. 4 Composite latitude-time sections of OLR (first and third rows, CI: $3 \mathrm{~W} \mathrm{~m}^{-2}$ ) and TRMM precipitation (second and fourth rows, CI: $1 \mathrm{~mm}$ day $^{-1}$ ) anomalies associated with eastward-propagating MJO events (left column, type-I), eastward-decaying MJO events (middle column, type-II), and eastward-intensifying MJO events

Indian Ocean seem coincident with the arrivals of strong circumnavigating upper-level divergent signals (VP200 $<0$, Fig. 5a, c), which originates in western Pacific about 30 days before. This upper-level divergence, however, is strongest over eastern (western) Pacific in association with enhanced local convection for type-I (-II) MJOs (Fig. 5a, c). The different intensifying locations of precedent VP200 signals may serve as extended-range precursors for these two MJO types. The potentially essential physical processes through which these precursory signals can lead to different MJO types are further investigated in next Sect. (3.2).

Both type-I and type-III MJOs exert robust downstream impacts over the WNP, ENP, and Atlantic basins during their active and precedent suppressed phases (Fig. 5a, b, e, f). In association with the precedent suppressed phases, (right column, type-III), respectively, over Indian sector (two upper panels, $60^{\circ} \mathrm{E}-100^{\circ} \mathrm{E}$ ) and western Pacific sector (two lower panels, $\left.120^{\circ} \mathrm{E}-160^{\circ} \mathrm{E}\right)$. Regions statistically significant above the $5 \%$ level are shaded and drawn with thick contours, whereas with thin contours for areas above the $25 \%$

coherent upper-level convergence anomalies (VP200 >0) and westerly vertical shear (U200-U850 >0) systematically move downstream followed with upper-level divergence and easterly vertical shear anomalies in association with the MJO active phases (Fig. 5a, b, e, f). In contrast to type-I and type-III MJOs, the convective signal of typeII MJO exerts little downstream impacts in Pacific and Atlantic basins (Fig. 5c, d). The upper-level convergence anomaly associated with the precedent suppressed phase of type-II MJO (Fig. 5c) is even stronger than that associated with type-I MJO over western Pacific, but weakens rapidly on its way eastward, so does the associated westerly vertical shear (Fig. 5d). During the active phase, the upper-level divergence and easterly vertical shear anomalies of type-II MJO are largely stalled in western MC as 
Fig. 5 Composite time-longitude sections of OLR anomalies (shading) overlaid with $200-\mathrm{hPa}$ velocity potential anomalies (contours, CI: $6 \times 10^{5} \mathrm{~m}^{2} \mathrm{~s}^{-1}$ ) and TRMM precipitation anomalies (shading) overlaid with (200-850-hPa) zonal wind shear (contours, CI: $1 \mathrm{~m} \mathrm{~s}^{-1}$ ) averaged between $5^{\circ} \mathrm{S}$ and $15^{\circ} \mathrm{N}$ for eastward-propagating MJO events (a, b, type-I), eastwarddecaying MJO events (c, $\mathbf{d}$, type-II), and eastward-intensifying $\mathrm{MJO}$ events (e, f, type-III). Thick and thin contours are regions with statistically significant levels above the 5 and $25 \%$

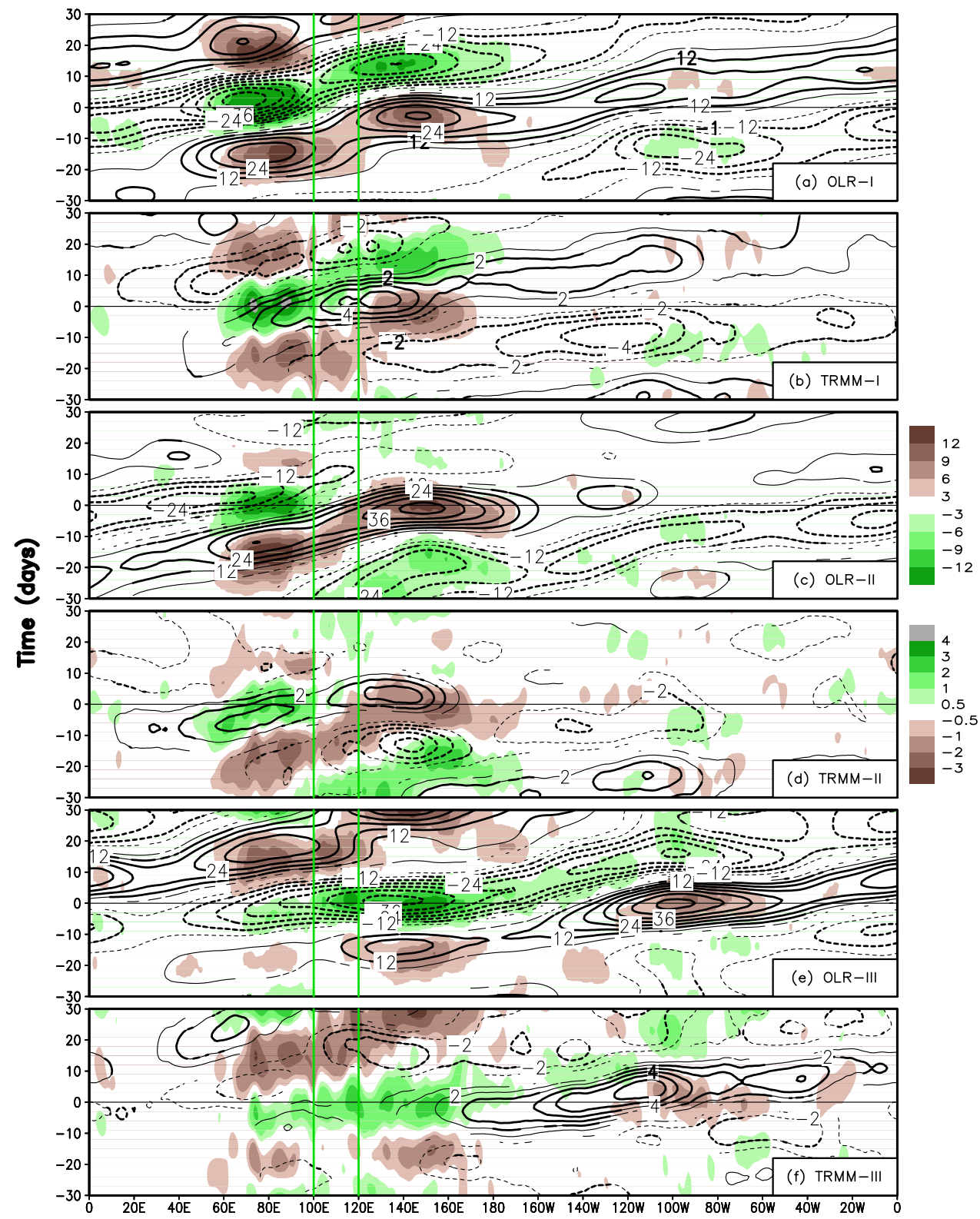

\subsection{Major physical processes distinguishing three MJO types}

\subsubsection{A global perspective}

Before we zoom into the Maritime Continent region, a broad view of the composite spatial-temporal life cycles of three MJO types in terms of large-scale convection (OLR) and upper-level divergence (VP200) anomalies over global tropics $\left(35^{\circ} \mathrm{S}-45^{\circ} \mathrm{N}\right)$ have been examined in Figs. 6, 7, and 8.

The life cycle of type-I MJO starts from a suppressed phase over the equatorial Indian Ocean and the formation 


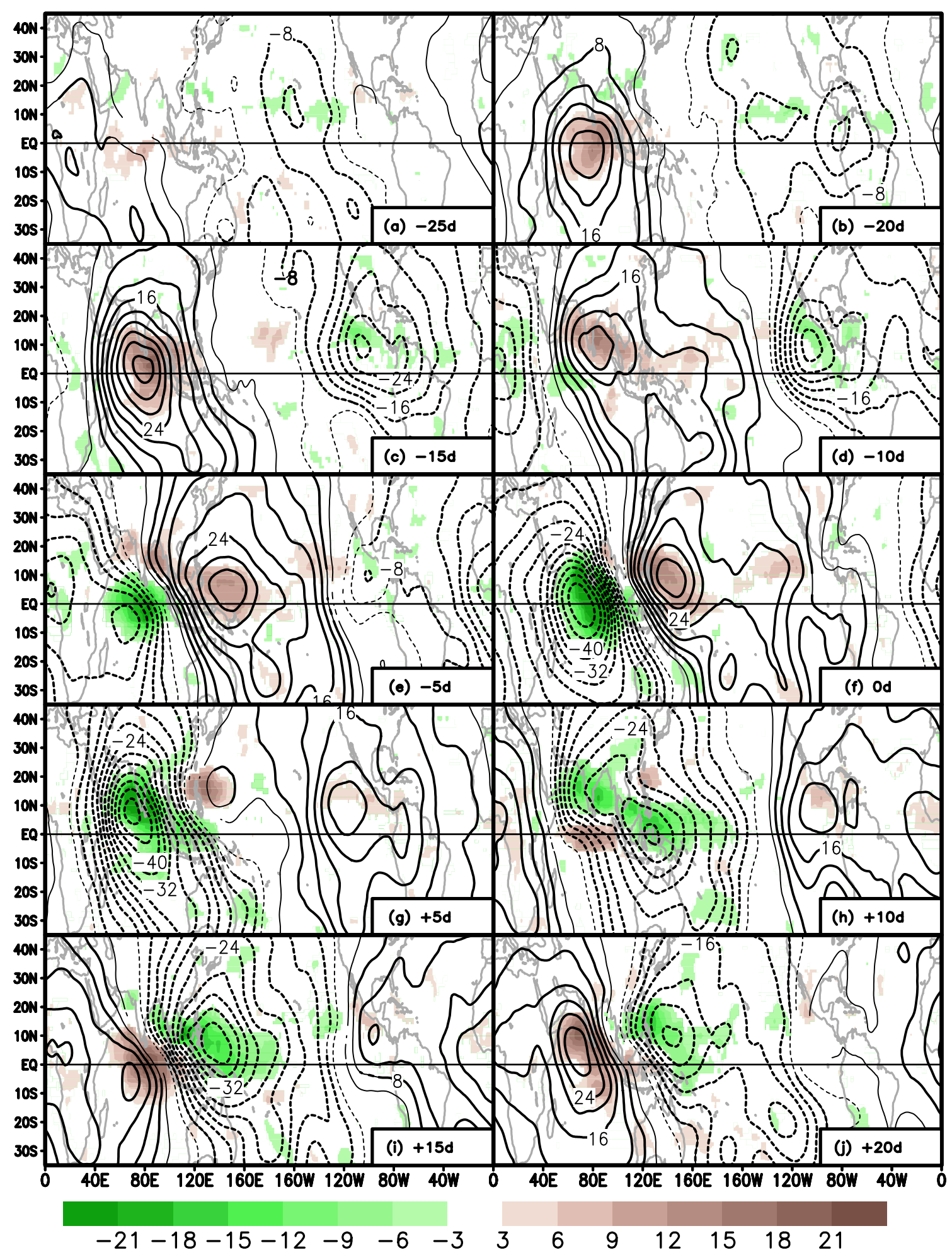

Fig. 6 Composite horizontal spatial-temporal evolutions of OLR anomalies (shading are regions with statistically significant level above the 5\%) and 200-hPa velocity potential anomalies (thick and thin contours are for significant levels above the 5 and $25 \%$, CI: $4 \times 10^{5} \mathrm{~m}^{2} \mathrm{~s}^{-1}$ ) associated with the life cycle of type-I MJO at day a $-25, \mathbf{b}-20, \mathbf{c}-15, \mathbf{d}-10, \mathbf{e}-5, \mathbf{f} 0, \mathbf{g}+5, \mathbf{h}+10, \mathbf{i}+15$, and $\mathbf{j}+20$ 


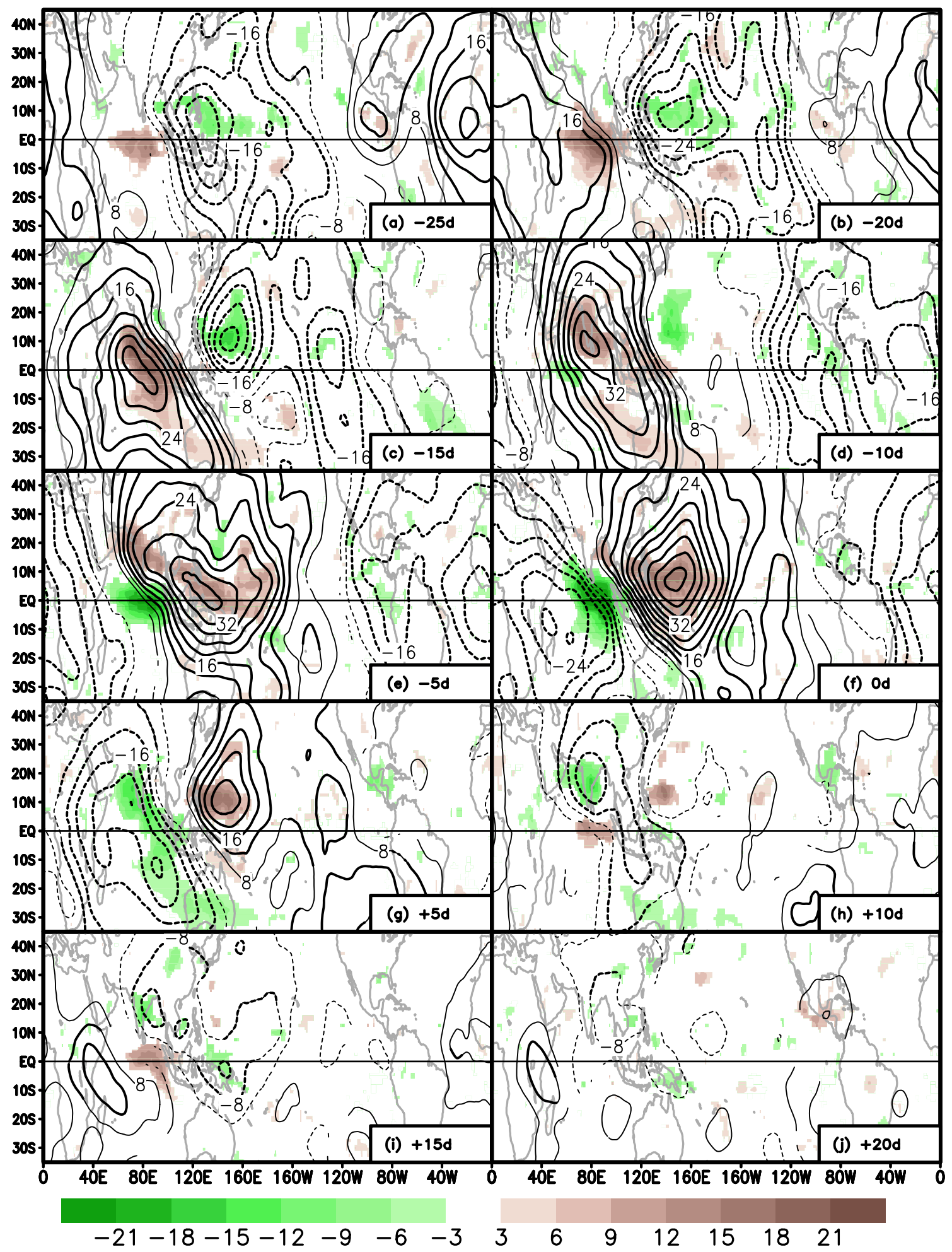

Fig. 7 Composite horizontal spatial-temporal evolutions of OLR anomalies (shading are regions with statistically significant level above the 5\%) and 200-hPa velocity potential anomalies (thick and thin contours are for significant levels above the 5 and $25 \%, \mathrm{CI}$ :
$4 \times 10^{5} \mathrm{~m}^{2} \mathrm{~s}^{-1}$ ) in association with the life cycle of type-II MJO at day $\mathbf{a}-25, \mathbf{b}-20, \mathbf{c}-15, \mathbf{d}-10, \mathbf{e}-5, \mathbf{f} 0, \mathbf{g}+5, \mathbf{h}+10, \mathbf{i}+15$, and $\mathbf{j}+20$ 


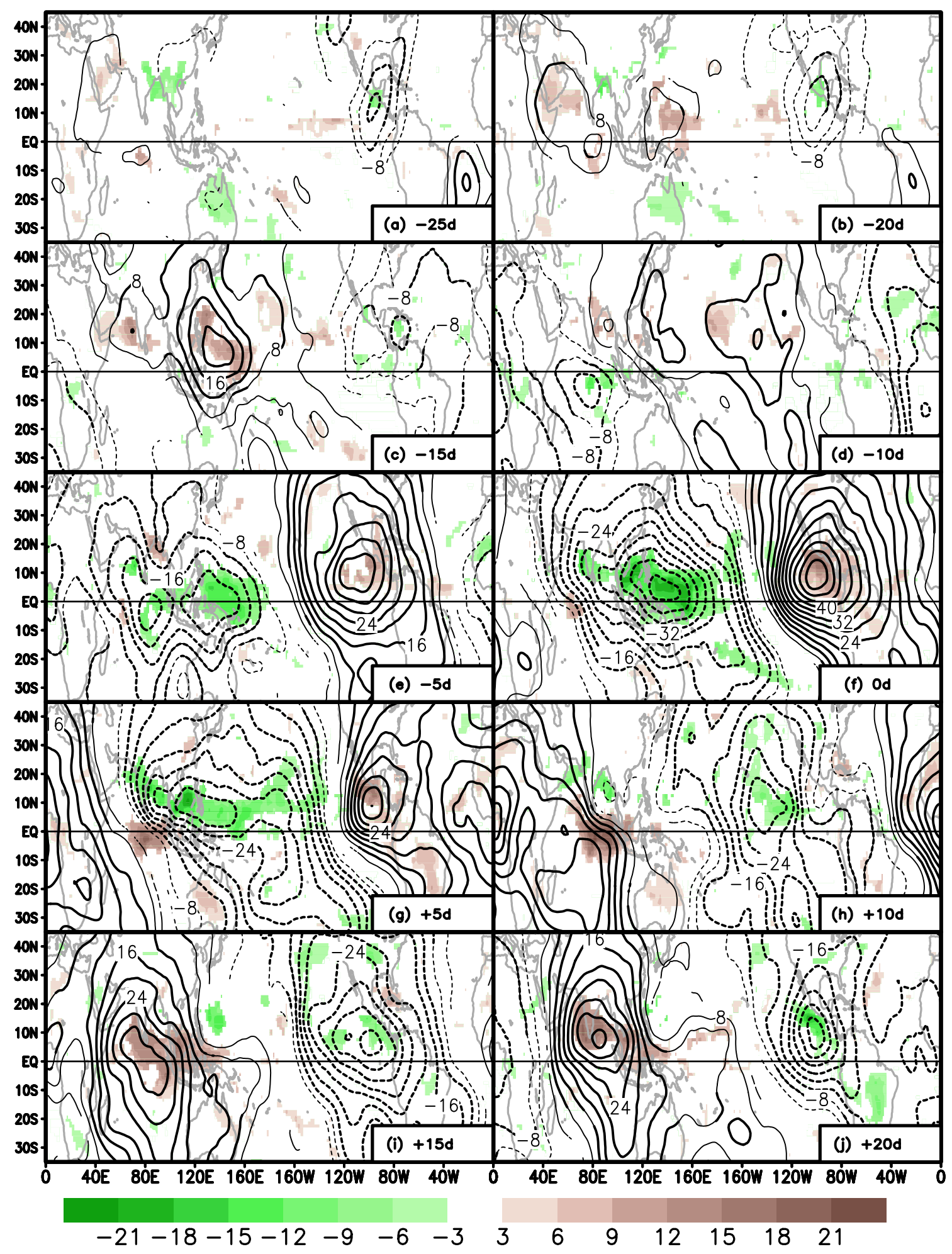

Fig. 8 Composite horizontal spatial-temporal evolutions of OLR anomalies (shading are regions with statistically significant level above the 5\%) and 200-hPa velocity potential anomalies (thick and thin contours are for significant levels above the 5 and $25 \%, \mathrm{CI}$ : $\left.4 \times 10^{5} \mathrm{~m}^{2} \mathrm{~s}^{-1}\right)$ in association with the life cycle of type-III MJO at day $\mathbf{a}-25, \mathbf{b}-20, \mathbf{c}-15, \mathbf{d}-10, \mathbf{e}-5, \mathbf{f} 0, \mathbf{g}+5, \mathbf{h}+10, \mathbf{i}+15$, and $\mathbf{j}+20$ 
of an upper-level convergent center (i.e., positive VP200 center) from day -25 (Fig. 6a) to day -20 (Fig. 6b), which is accompanied by slightly enhanced convection over Asian summer monsoon trough and northern Pacific ITCZ. Along with the continuous intensification of the dry phase and upper-level convergence in Indian Ocean at day - 15, an enhanced convection and upper-layer divergent center (i.e., negative VP200 center) emerges over the ENP (Fig. 6c). Thus, a reversed anomalous Walker-type overturning circulation is established with rising branch over eastern Pacific and sinking branch over Indian Ocean. On day -10 (Fig. 6d), the wet phase of type-I MJO initiates over the western Indian Ocean slightly before the arrival of upperlevel divergence. Likely, the onset of type-I MJO convection is due to the low-level convergence driven by atmospheric subsidence in association with the dry phase over Indian Ocean and the MC (Wang et al. 2005). The arrival of upperlevel divergence may contribute to the development of MJO convection (Roundy 2014). Along with the intensification and eastward shift of convection over tropical Indian Ocean, the precedent dry phase moves northward and eastward to form a tilted dry belt extending from Indian peninsula to equatorial western Pacific (Fig. 6e, f). At the same time, the upper-level divergent and convergent centers, respectively, moves to the tropical Indian Ocean and WNP to form a strong cross-South-China-Sea (SCS) northeast-southwest overturning cell. ${ }^{1}$ The steady eastward propagation of upperlevel convergence from western Pacific to eastern Pacific and northeastward movement of the convection in Indowestern Pacific sector eventually lead to an enhanced crossPacific east-west cell ${ }^{2}$ with its sinking branch in the ENP and rising branch over the MC region (Fig. $6 \mathrm{~g}, \mathrm{~h}$ ). In the following two pentads (Fig. 6i, j), a dry phase is formed and gradually intensified over the tropical Indian Ocean along with the wet phase moving northeastward. An overturning cell with its ascending branch over the WNP and sinking branch over tropical Indian Ocean is thus established. During the life cycle of type-I MJO, the associated large-scale overturning circulations alternatively dominate with crossPacific east-west cells (e.g., Fig. 6d, h) and cross-SCS northeast-southwest cells (e.g., Fig. 6f, j).

For type-II MJO (Fig. 7), the initiation and intensification of a suppressed phase over Indian Ocean at day -25 , -20 , and -15 (Fig. 7a-c) are accompanied with a persistent wet phase over the WNP. The associated overturning circulation primarily resides in Indo-western Pacific sector

\footnotetext{
1 The cross-SCS northeast-southwest cell manifests as VP200 and convection dipoles with two obvious out-of-phase centers, respectively, in the tropical Indian Ocean and western north Pacific.

2 The cross-Pacific east-west cell manifests as VP200 and convection dipoles with two obvious out-of-phase centers, respectively, in the Indo-MC-western Pacific region and eastern north Pacific.
}

with a cross-SCS northeast-southwest cell without a robust cross-Pacific east-west cell as seen in type-I MJO (Fig. 6b, c). The onset of the wet phase over western Indian Ocean at day -10 (Fig. 7d) is likely due to the dry phase over northern Indian Ocean and the MC as for type-I MJO (Fig. 6d). When the convection intensifies and moves toward the MC during day -5 and 0 , the precedent dry phase also intensifies and moves into western Pacific (Fig. 7e, f). During next two pentads (day +5 and +10 in Fig. $7 g, h$ ), the dry phase over the WNP decays locally instead of propagating eastward to the ENP. The wet phase over Indian Ocean also dissipates rapidly over the MC. During the life cycle of type-II MJO, the associated large-scale overturning circulation dominates with a cross-SCS northeast-southwest cell. The persistent wet phase over the WNP preceding and during the onset of type-II MJO convection (Fig. 7a-d) and the lack of a robust cross-Pacific east-west overturning cell are two robust features different from type-I MJO and may be responsible for the rapid decay of type-II MJOs during their passages over the MC. The associated physical processes will be further investigated in following sections.

For type-III MJO (Fig. 8), during day $-25,-20$, and -15 , a weak dry phase develops in the equatorial Indian Ocean (Fig. 8a) and moves northeastward (Fig. 8b, c). During the same period, a modest convection develops over the ENP and Central America collocating with an upper-level divergent center. In the wake of the eastward-moving dry phase, a weak convective signal of type-III MJO starts to form over South Africa (Fig. 8c). On day - 10 (Fig. 8d), the convection and upper-level divergence shift eastward and intensify over Indian Ocean. At the same time, the preceding dry phase and upper-level convergence gradually move from the WNP to ENP. The convection at next pentad (at day -5 in Fig. 8e) intensifies rapidly and a robust anomalous Walker-type circulation is established with a rising branch over western Pacific and a sinking branch over the ENP. At day 0 , along with the intensified convection over western Pacific, a dry phase starts to form over the equatorial Indian Ocean (Fig. 8f). During next two pentads (day +5 and +10 ), the wet phase in western Pacific gradually decays and moves to eastern Pacific (Fig. 8g, h). On day +15 and +20 , a reversed Walker-type circulation is established with a rising branch over the ENP and a sinking branch over Indo-western Pacific (Fig. 8i, j). The life cycle of type-III MJO, thus, dominates with a cross-Pacific east-west overturning cell.

The above results demonstrate that three boreal-summer MJO types have distinctive large-scale overturning circulations in association with their life cycles. For type-I MJO, a cross-Pacific east-west cell and a cross-SCS northeastsouthwest cell dominate alternatively. For type-II MJO, only a cross-SCS northeast-southwest cell is the dominant overturning circulation. For type-III MJO, only a cross-Pacific east-west cell is the dominant overturning circulation. The 
underlying physical processes that lead to the formations of different overturning-circulation regimes and their roles on determining MJO types deserve further study.

\subsubsection{A regional perspective}

In this section, we zoom into the Indo-MC-western Pacific sector and focus on the preconditioning and transitioning periods during MJO passages over the MC. Previous studies have identified three processes as potentially important factors governing the downstream evolutions of the MJO. They are positive SST anomalies ahead of MJO convection (e.g., Krishnamurti et al. 1988; Hirata et al. 2013), low-level convergence arising from the interactions between the MC orography and easterly anomalies resulting from Kelvinwave response to Indian Ocean convection (Hsu and Lee 2005), and a robust dry phase over the MC and western Pacific (Kim et al. 2014). These processes and their potential influences on three MJO types are examined in this section.

Figure 9 shows the composite convection and SST anomalies in association with the passages of three MJO types over the MC. For type-I and type-II MJOs, we focus on day -5 and 0 . For type-III MJO, the focus is on day -10 and -5 . To ensure the robustness of our results, the composites with 12-year TRMM precipitation and TMI SST as well as 21-year NOAA OLR and CFSR SST are examined together. On day -5 , both type-I and type-II composites have a MJO wet phase over Indian Ocean and a tilted dry belt extending from the Arabian Sea, Indian Peninsula, and Bay-ofBengal all the way to the SCS, and equatorial western Pacific (Fig. 8a, c, e, g). Along with the dry zone, a band of coherent positive SST anomalies forms over the northern Indian Ocean, SCS, and WNP for type-I MJO (Fig. 9a, c), while the positive SST anomalies for type-II MJO are basically limited to northern Indian Ocean (Fig. 9e, g). Although a small patch of positive SST anomaly appears in the northern marginal sea of New Guinea in CFSR (Fig. 9g), no apparent signal emerges in TMI SST (Fig. 9e). On day 0 of type-I MJO (Fig. 9b, d), significant positive SST anomalies have been established over the Bay of Bengal, SCS, and equatorial western Pacific, thus providing a favorable condition for the northward propagation of equatorial convection in Indian Ocean and its eastward movement over the MC (Fu and Wang 2004; Wang et al. 2005, 2006). For type-II MJO at day 0 (Fig. 9f, h), robust positive SST anomalies only present over the Arabian Sea and Bay of Bengal along with weak positive SST anomalies scattering over the MC marginal seas. This spatial distribution of SST anomalies favors the northward propagation of type-II MJO over Indian sector (Fig. 4e, f) but not the eastward propagation over the MC (Fig. 1b, e). For type-III MJO, the period from day -10 to -5 represents the rapid transitioning of MJO-related convection from eastern Indian Ocean to the $\mathrm{MC}$ and equatorial western Pacific (Fig. 8d, e). In response to the subsidence over northern Indian Ocean, the MC, and western Pacific during day -20 and -15 (Fig. 8b, c), weak yet coherent positive SST anomalies form in the above regions (Fig. 9i, k), which may not play an essential role, but indeed provide a favorable condition for the intensification of convection over the MC and western Pacific (Fig. 9j, 1).

The low-level (850-hPa) divergence and horizontal wind anomalies along with SLP anomalies in association with three MJO types during their preconditioning and transitioning over the MC are, respectively, given in Figs. 10, 11, 12 and 13 . The target period is from day -10 to day +5 for type-I (Fig. 10) and type-II (Fig. 11) MJOs, but from day -15 to 0 for type-III MJO (Fig. 12). For type-I MJO on day -10 , an anti-cyclonic circulation (Fig. 10a) and an anomalous high (Fig. 13a) present over northern Indian Ocean along with a tilted dry zone. The westerly wind anomalies near the dateline (Fig. 10a) and positive SLP anomalies over the equatorial Pacific (Fig. 13a) signify a Kelvin-wave-like response to the dry phase over Indo-MC-western Pacific sector. The easterly anomaly over northern Indian Ocean weakens mean monsoon westerly, thus, reducing evaporation there. Along with the enhanced solar radiation, significant positive SST anomalies are produced over northern Indian Ocean and underneath the tilted dry zone (Fig. 9a, c). At next pentad (day -5), the MJO convection over the equatorial Indian Ocean grows rapidly with its front reaching western MC (Fig. 10b). Easterly anomalies in front of the convection extend all the way from the equatorial western Pacific, SCS, to the Bay of Bengal and Arabian Sea as a response to the eastward expansion of negative SLP anomalies along the equator and intensified positive SLP anomaly over the northern SCS and WNP (Fig. 13b). The resultant decrease of surface evaporation and increase of solar radiation further amplify the positive SST anomalies in above regions (Fig. 9b).

During next two pentads (day 0 and +5 ) of type-I MJO (Figs. 13c, d, 10c, d), a Kelvin-wave-like negative SLP tongue in response to the MJO convection over Indian Ocean smoothly propagates over the MC and enters the equatorial Pacific replacing the decayed positive SLP anomaly in association with the precedent dry phase (Fig. 13c, d), very similar to the scenario documented in Matthews (2000). At the same time (Fig. 10c, d), the dry phase over western Pacific shrinks and moves to the northern SCS and WNP. The easterly anomalies as partly forced by the positive SLP anomalies over the SCS and WNP and partly by a Kelvinwave-like response are significantly strengthened over the equatorial western Pacific. The interactions between the enhanced easterly anomalies and MC terrains lead to strong surface convergence (Hsu and Lee 2005), which preconditions the lower troposphere over the MC and provides a favorable condition for the smooth transitioning of Indian 

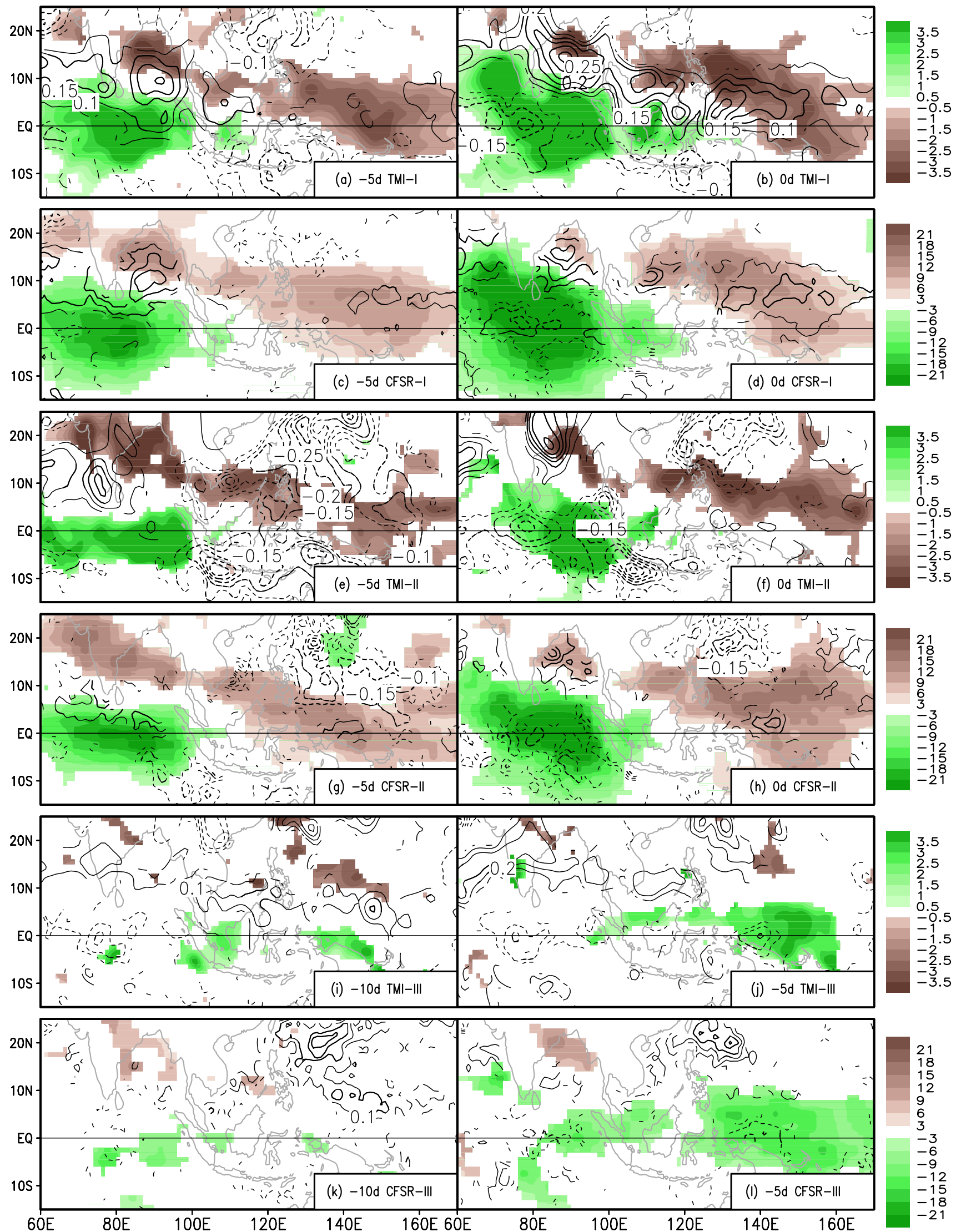
4Fig. 9 Composite spatial-temporal evolutions of convection (precipitation and OLR, shading are regions with statistically significant level above the 5\%) and SST (thick and thin contours are for significant levels above the 5 and $25 \%$, CI: $0.05{ }^{\circ} \mathrm{C}$ ) anomalies during the passages of three MJO types over the MC: TRMM precipitation and TMI SST at day $\mathbf{a}-5$ and $\mathbf{b} 0$ for type-I; OLR and CFSR SST at day $\mathbf{c}-5$ and $\mathbf{d} 0$ for type-I; TRMM precipitation and TMI SST at day $\mathbf{e}$ -5 and $\mathbf{f} 0$ for type-II; OLR and CFSR SST at day $\mathbf{g}-5$ and $\mathbf{h} 0$ for type-II; TRMM precipitation and TMI SST at day $\mathbf{i}-10$ and $\mathbf{j}-5$ for type-III; OLR and CFSR SST at day $\mathbf{k}-10$ and $\mathbf{l}-5$ for type-III

Ocean MJO convection cross the MC and entering the equatorial western Pacific.

For type-II MJO on day - 10 (Figs. 11a, 13e), westerly anomalies instead of easterly anomalies prevail over the northern Bay of Bengal, SCS, and WNP as a response to a deep trough over the WNP (Fig. 13e). The westerly anomalies enhance mean monsoon flows, thus increasing upward surface latent heat flux. The opposite effects of surface latent heat flux and solar radiation in this case result in negligible positive SST anomalies over the dry zone (Fig. 9e, g).
However, over most northern Indian Ocean, where positive SST anomalies develop from the enhanced solar radiation and reduced evaporation due to anomalous easterly acting on mean westerly flows. On day -5 (Figs. $11 \mathrm{~b}, 13 \mathrm{f}$ ), the MJO convection over Indian Ocean intensifies and moves close to western MC while the convection and associated negative SLP anomaly over the WNP weaken and move northward. The easterly anomalies in Indian Ocean also move northward to the Arabian Sea and Bay of Bengal, so does the positive SST anomalies (Fig. 9f, h). Weak easterly anomalies also start to form over the southern SCS and northern marginal sea of New Guinea, leading to the development of weak positive SST anomalies there (Fig. 9f, h).

During the next two pentads (day 0 and +5 ) of typeII MJO (Figs. 13g, h, 11c, d), the positive SLP anomalies over the equatorial Pacific and WNP as a response to the strong dry phase in the WNP block the Indian Ocean MJO convection to generate a robust Kelvin-wave-like response in the equatorial Pacific (Fig. 13g, h). Therefore, no equatorial symmetric easterly presents over the $\mathrm{MC}$ and western

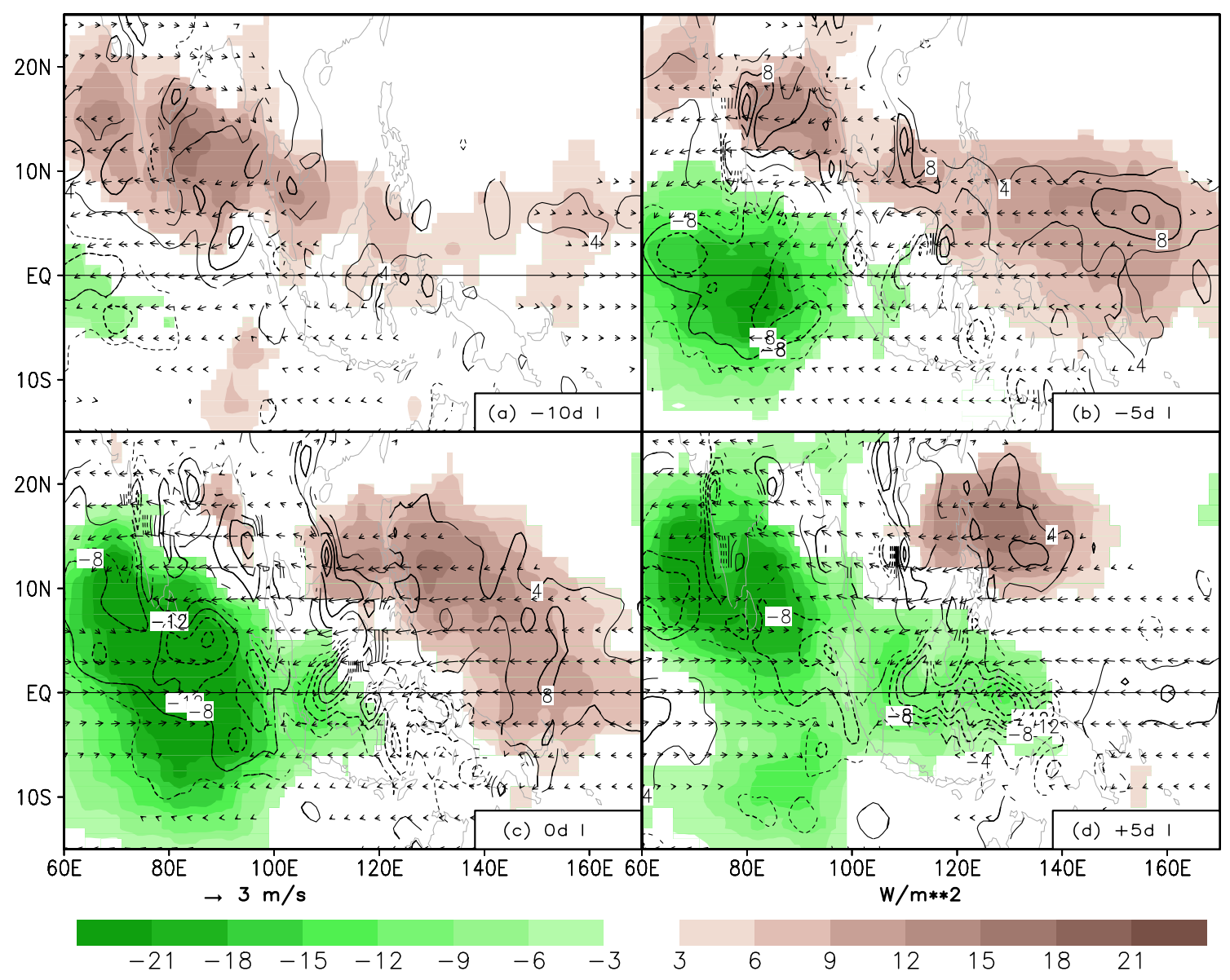

Fig. 10 Composite spatial-temporal evolutions of OLR (shading are regions with statistically significant level above the 5\%), surface convergence (thick and thin contours are for significant levels above the
5 and $25 \%$, CI: $4 \times 10^{-7} \mathrm{~s}^{-1}$ ) and wind anomalies (vectors are regions with statistically significant level above the 5\%) during the passage of type-I MJO over the MC at day $\mathbf{a}-10, \mathbf{b}-5, \mathbf{c} 0$ and $\mathbf{d}+5$ 


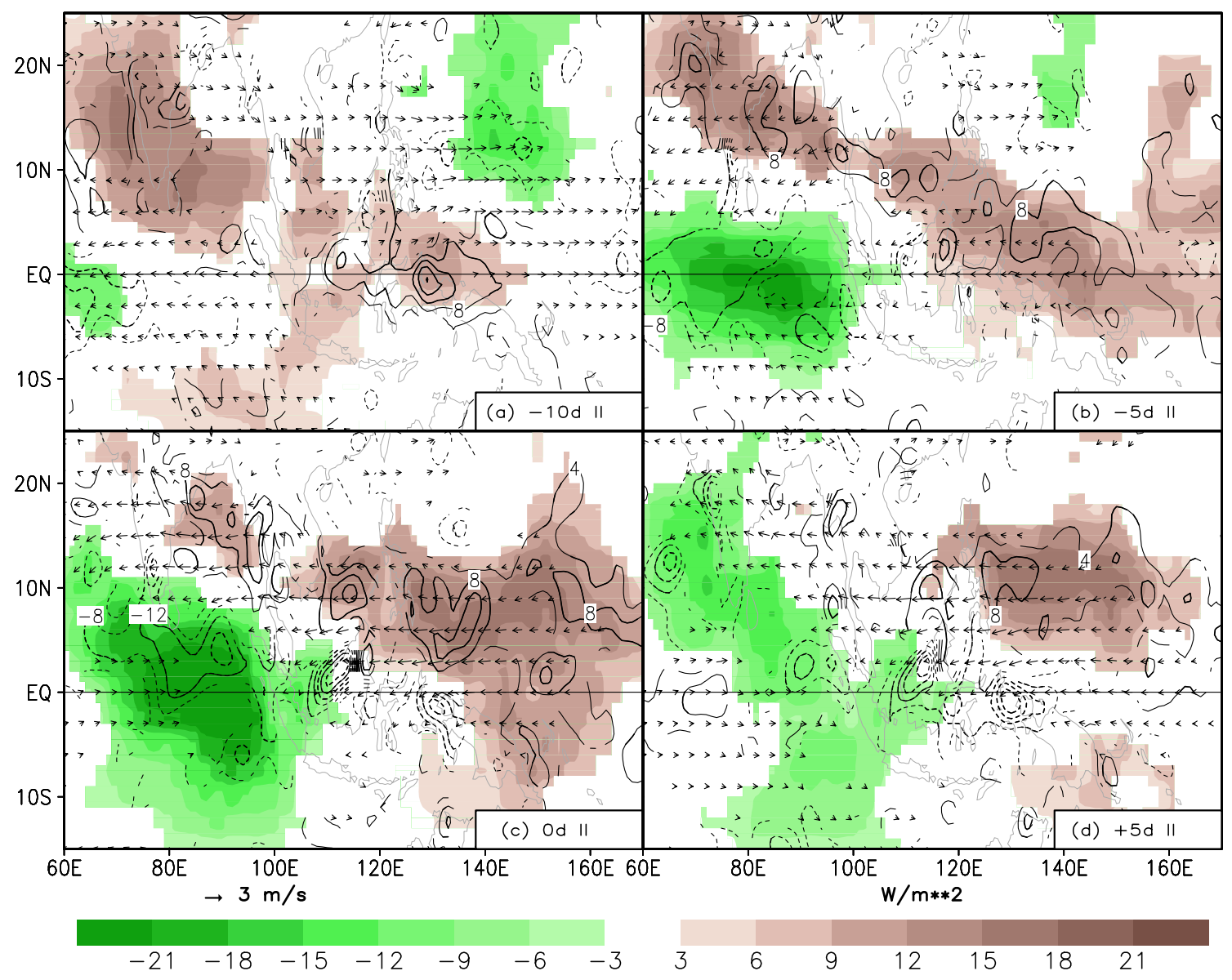

Fig. 11 Composite spatial-temporal evolutions of OLR (shading are regions with statistically significant level above the 5\%), surface convergence (thick and thin contours are for significant levels above the

Pacific (Fig. 11c, d) as in type-I MJO (Fig. 10c, d). Instead, the easterly anomaly in western Pacific for type-II MJO is largely confined in Northern Hemisphere (Fig. 11c, d) as a response to the strong positive SLP anomalies over the SCS and WNP. The small positive SST (Fig. 9e, f, g, h) and weak easterly wind anomalies around the $\mathrm{MC}$ and western Pacific lead to insufficient preconditioning of the lower troposphere over the MC and western Pacific, which eventually results in the rapid decay of Indian Ocean MJO convection over the MC. This non-propagating MJO scenario in boreal summer is quite different from the scenario depicted in Kim et al. (2014), who mixed the cases year-around together and found that a robust precedent dry phase over western Pacific favors the eastward propagation of Indian Ocean MJO convection. Our results suggest the opposite for the boreal summer: The strong precedent dry phase over western Pacific leads to stalled MJO convection in Indian Ocean through inhibiting the formation of a robust Kelvin-wave-like response to Indian Ocean MJO convection over the MC and equatorial western Pacific.
5 and $25 \%$, CI: $4 \times 10^{-7} \mathrm{~s}^{-1}$ ) and wind anomalies (vectors are regions with statistically significant level above the 5\%) during the passage of type-II MJO over the MC at day $\mathbf{a}-10, \mathbf{b}-5, \mathbf{c} 0$ and $\mathbf{d}+5$

For type-III MJO (Fig. 12), the evolutions in Pacific sector are very similar to the type-I (Fig. 10), but with much weaker perturbations in Indian sector. On day -15 (Figs. 12a, 13i), coherent dry phase and positive SLP anomalies present over the northern Indian Ocean and western Pacific similar to type-I MJO (e.g., Fig. 13a, i) but with a weaker amplitude. Also in a similar fashion, easterly anomalies are generated over the northern Indian Ocean, SCS, and equatorial western Pacific, which in turn establishes coherent positive SST anomaly over the above regions (Fig. 9i, k). At next pentad (day - 10, Figs. 12b, 13j), the dry phase over the MC and western Pacific decays rapidly. The associated positive SLP anomaly also moves eastward into eastern Pacific quickly (Fig. 13i, j). At the same time, weak convection presents over the MC. In next two pentads (day -5 and 0 in Figs. 13k, 1, 12c, d), a Kelvin-wave-like negative SLP tongue as a response to MJO convection around the MC is considerably amplified over the equatorial Pacific on its way eastward (Fig. 13k, 1), which leads to a rapid intensification of the MJO convection in western Pacific (Fig. 12c, d). 


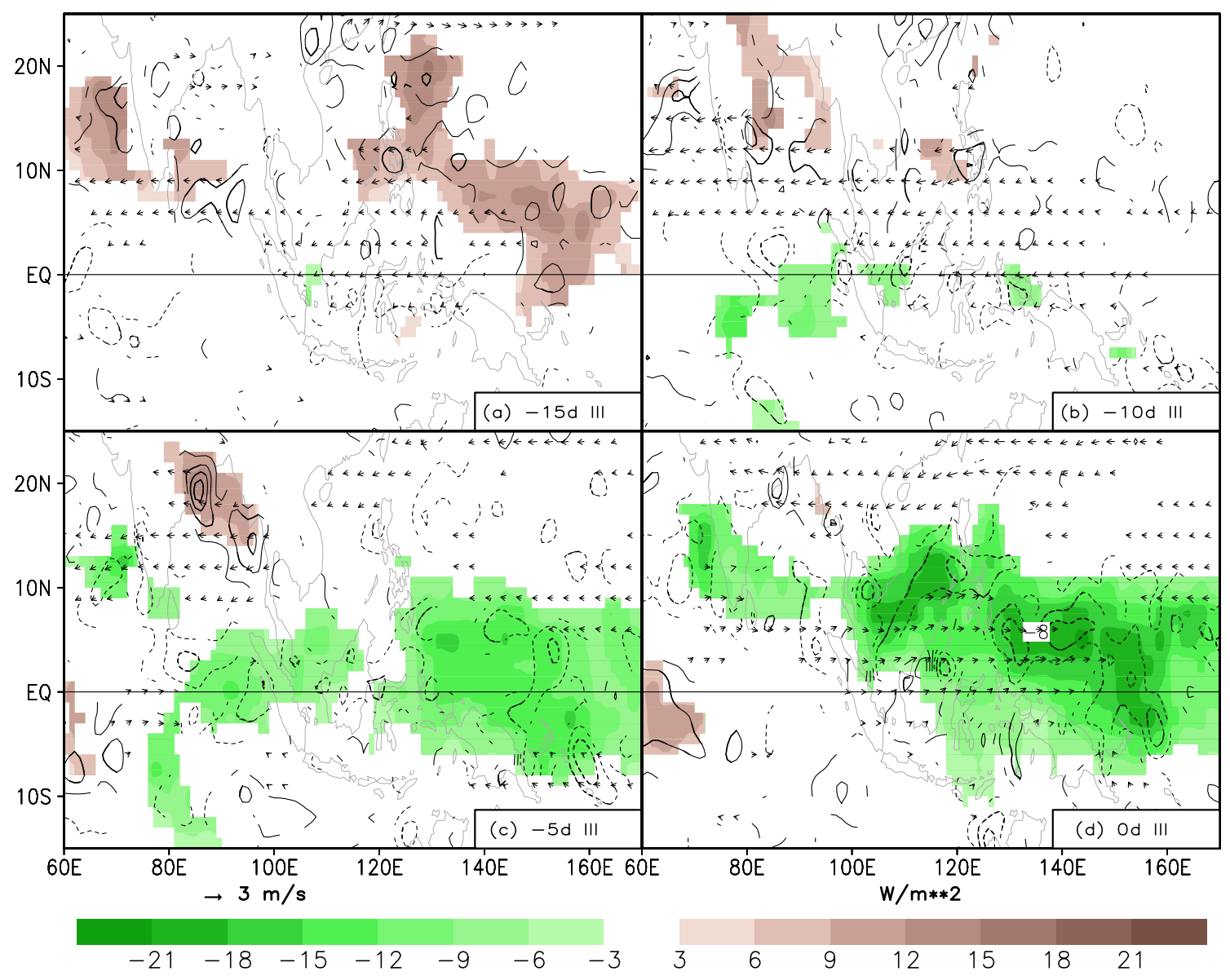

Fig. 12 Composite spatial-temporal evolutions of OLR (shading are regions with statistically significant level above the 5\%), surface convergence (thick and thin contours are for significant levels above the
5 and $25 \%$, CI: $4 \times 10^{-7} \mathrm{~s}^{-1}$ ) and wind anomalies (vectors are regions with statistically significant level above the 5\%) during the passage of type-III MJO over the MC at day $\mathbf{a}-15, \mathbf{b}-10, \mathbf{c}-5$ and $\mathbf{d} 0$
Likely, the convection amplification over western Pacific is also related to the formation of an enhanced Walker-type circulation over the tropical Pacific as illustrated in Fig. 8e, f.

With a regional perspective, the convection of type-I and type-III MJOs over eastern Indian Ocean and the MC is able to force robust Kelvin-wave-like SLP and wind responses and coherent positive SST anomalies over the MC and western Pacific. These two synchronized factors along with the enhanced Pacific basin-wide Walker-type circulations (Figs. 6g, h, 8e, f) overcome the MC barrier and smoothly propagate the MJO convection into western Pacific. On the other hand, the persistent WNP convection that co-exists with type-II MJO likely plays an essential role to stall the MJO-related convection in Indian Ocean through a chain of processes. It blocks the smooth northward movement of the dry phase over the MC and western Pacific, thus inhibiting the formations of coherent positive SST anomalies and a robust Kelvin-wave-like response in the above regions, at the same time, failing to establish a robust Pacific basin-wide Walker-type cell over the equatorial Pacific. These results suggest that if the MJO convection in Indian Ocean can't create favorable downstream responses over the MC and tropical Pacific, it becomes vulnerable to the hostile environments around the $\mathrm{MC}$ and subject to rapid decay during its passage over the MC. In general, this scenario substantiates the finding of Stachnik et al. (2015), who also emphasized that the downstream responses of the MJO largely determine its own fate.

\subsubsection{Vertical moisture structures near the Maritime Continent}

In order to further understand the moist processes that distinguish the downstream evolutions of three MJO types over the MC, Fig. 14 gives the vertical structures of moisture anomalies, their tendencies and associated budget terms (Yanai et al. 1973) when the composite MJO convection reaches western MC at day 0 for type-I and type-II MJOs, and day -10 for type-III MJO (e.g., see Figs. 10c, 11c, 12b). 


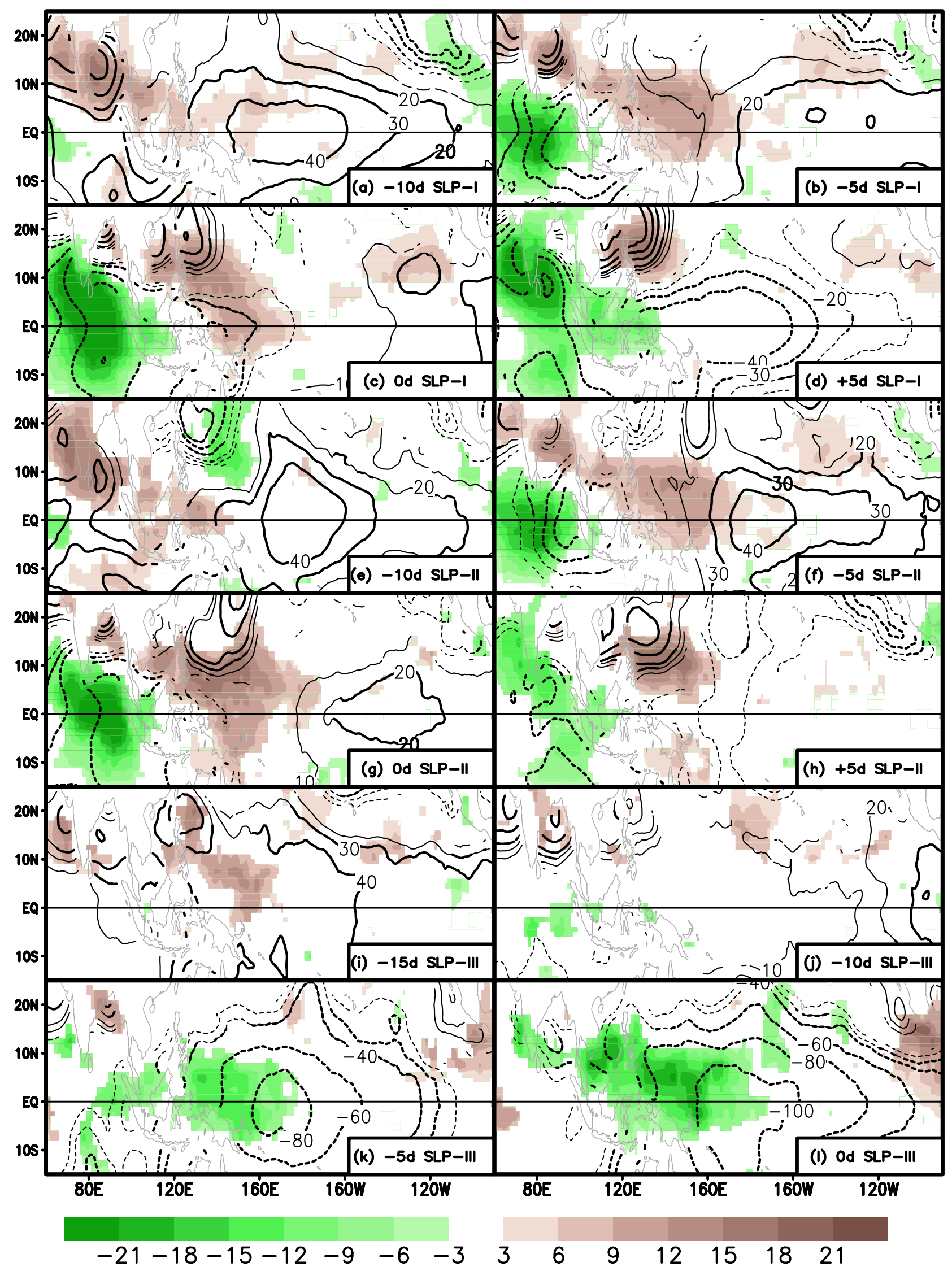


4Fig. 13 Composite spatial-temporal evolutions of OLR (shading are regions with statistically significant level above the 5\%) and sea level pressure (thick and thin contours are for significant levels above the 5 and 25\%); [contour levels ( \pm ): 5, 10, 20, 30, 40, 60, 80, $100 \mathrm{~Pa}$ ] anomalies during the passages of three MJO types over the MC: the type-I at day $\mathbf{a}-10, \mathbf{b}-5$, $\mathbf{c} 0$ and $\mathbf{d}+5$; the type-II at day $\mathbf{e}-10, \mathbf{f}$ $-5, \mathbf{g} 0$ and $\mathbf{h}+5 ;$ the type-III at day $\mathbf{i}-15, \mathbf{j}-10, \mathbf{k}-5, \mathbf{l} 0$

For type-I (Fig. 14a) and type-III MJOs (Fig. 14c), positive moisture anomalies develop in the lower troposphere over the MC and boundary-layer over western Pacific. Positive moisture tendencies also dominate in the entire troposphere over the MC and western Pacific. On the other hand, for type-II MJO (Fig. 14b), significant negative moisture anomalies due to strong subsidence (Fig. 7f) still occupies the entire troposphere over western Pacific. Although positive moisture tendency appears in the troposphere over the MC and boundary layer over western Pacific, negative moisture tendency prevails in the troposphere over western Pacific.

The apparent moisture sources (the reversed apparent moisture sinks, Fig. 14d-f) are positive over the MC and western Pacific in all three cases likely due to the evaporation of cloud liquid water (Yanai et al. 1973; DeMott et al. 2014) and the detrainments of cloud water from shallow cumulus and congestus (Johnson et al. 1999). Around $100^{\circ} \mathrm{E}$ and $120^{\circ} \mathrm{E}$ (Fig. $14 \mathrm{~g}-\mathrm{i}$ ), the easterly wind anomalies (Figs. 10c, 11c, 12b) as Kevin-wave-like responses to Indian Ocean MJO convection and also as driven by the positive SLP anomaly over the WNP (Fig. 13c, g, j) interact with Sumatra islands and Philippine island chain to force vigorous upward moisture advection (Hsu and Lee 2005). Horizontal advections also tend to moisten the boundary layer and troposphere over the MC and western Pacific for all three MJO types (Fig. 14j-1).
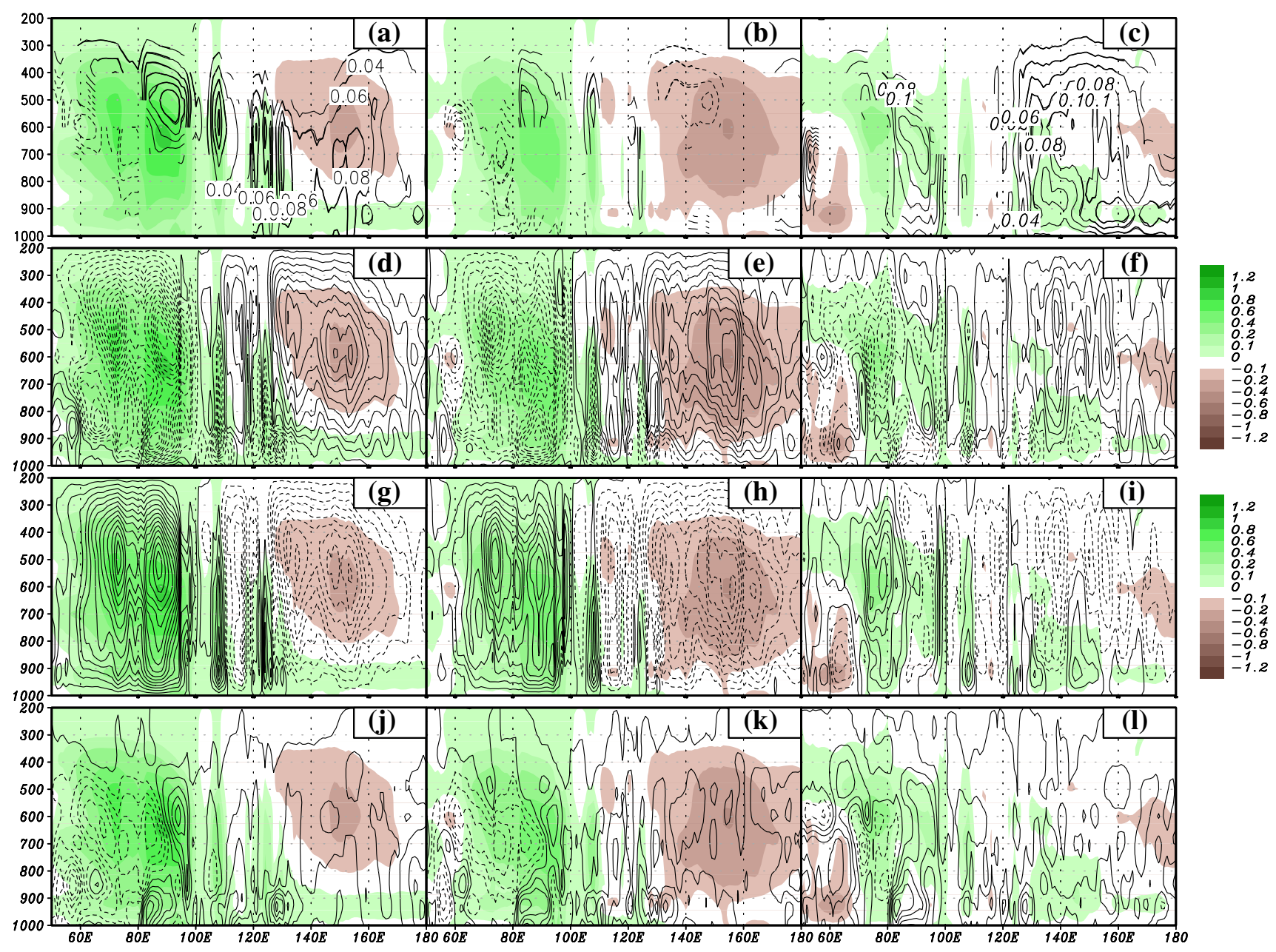

Fig. 14 Composite vertical structures of moisture anomalies (shading, $\mathrm{g} \mathrm{kg}^{-1}$ ) and associated budget terms (contours, unit: $1 \times 10^{-7} \mathrm{~g} \mathrm{~kg}^{-1} \mathrm{~s}^{-1}$ ) during their passages over the Maritime Continent averaged over $5^{\circ} \mathrm{S}-10^{\circ} \mathrm{N}$ for three MJO types: type-I, -II, and -III at day 0 (left, middle and right column), a-c moisture tendency (CI:
0.08), $\mathbf{d}-\mathbf{f}$ apparent moistening source (CI: 0.4), $\mathbf{g}-\mathbf{i}$ vertical moisture advection (CI: 0.4), and $\mathbf{j}-\mathbf{l}$ horizontal moisture advection (CI: 0.4). Moisture tendencies (a-c) with statistically significant levels above the 5 and $25 \%$ are drawn in thick and thin contours 
DeMott et al. (2014) and Feng et al. (2015) have suggested that positive column-integrated moisture tendency ahead of Indian Ocean MJO convection is the key factor to ensure MJO propagation over the MC. The above result, however, suggests that the positive moisture tendency alone is not a sufficient condition. For the non-propagating type-II MJO (Fig. 1b, e), there is a clear positive column-integrated moisture tendency presenting ahead of its Indian Ocean convection over the MC (Fig. 14b). It is likely that the extreme mid-tropospheric dryness and negative moisture tendency over western Pacific inhibits the further eastward propagation of type-II MJO. Our results, however, suggest that the combination of positive boundary layer moisture anomalies and column-integrated moisture tendencies along with weak mid-tropospheric dryness ahead of Indian Ocean MJO convection (Fig. 14a, c) are key factors that ensure smooth MJO propagation over the MC.

\section{Discussions and concluding remarks}

During boreal summer, in addition to the year-around eastward-propagating $\mathrm{MJO}$, the intra-seasonal events over the Indo-Pacific warm-pool also own a dominant northwardpropagating component, which strongly modulates Asian summer monsoon wet and dry spells. The equatorial eastward-propagating $\mathrm{MJO}$, on the other hand, strongly modulates tropical cyclone activities over the Indian Ocean, WNP, ENP and Atlantic basin. Based on their downstream fates after reaching the $\mathrm{MC}$, three distinctive MJO types are identified in this study (Figs. 1,2): (i), the type-I smoothly transitions over the MC from Indian Ocean to western Pacific; (ii), the type-II has similar evolution as the type-I over Indian Ocean but rapidly decays over the MC; (iii), the type-III has very weak amplitude in Indian Ocean but significantly intensifies on its passage over the MC. Type-I, -II, and -III MJOs, respectively, accounts for about 56, 25, and $19 \%$ of total boreal-summer MJO events (Table 1).

Both type-I and type-III MJOs have strong downstream impacts over the WNP, ENP and Atlantic basin but not typeII MJO (Fig. 5), which has strong activity only over Indian sector, but with negligible downstream impacts over Pacific and Atlantic basins. Coherent northward-propagating ISOs exist in both Indian and western Pacific sectors in association with both type-I and type-III eastward-propagating MJOs (Fig. 4). However, type-II MJO only has associated robust northward-propagating ISO over Indian sector, which resembles the independent northward-propagating monsoon ISO in Wang and Rui (1990) and Lawrence and Webster (2002). In this sense, about $25 \%$ of total boreal-summer MJO events over Indo-western Pacific sector can be classified as independent northward-propagating mode, while the remaining $75 \%$ has robust eastward-propagating component.

Global and regional perspectives have been taken to understand the potentially important processes that govern three MJO types. It is found that for both type-I and III MJOs, their life cycles are associated with robust alternative Pacific basin-wide overturning circulations (Figs. 6, 8) but not for type-II MJO, which is dominated with regional alternative overturning circulations between the tropical Indian Ocean and WNP (Fig. 7). The existence of Pacific basin-wide overturning circulations in association with boreal-summer MJO has long been recognized (e.g., Krishnamurti et al. 1985; Lau and Chan 1986; Knutson et al. 1986; Rydbeck et al. 2013). As our knowledge, present study demonstrated for the first time that if no robust Pacific basinwide overturning circulation can be established, boreal-summer Indian Ocean MJO events will develop a robust regional overturning circulation across the SCS between the tropical Indian Ocean and WNP. Why type-II MJO fails to establish a robust Pacific basin-wide overturning circulation warrants further diagnostic and modeling studies.

Focusing on the transitioning periods of three MJO types over the MC, it is found that in association with the development of type-II MJO convection in Indian Ocean, a persistent convection exists over the WNP (Figs. 7c-e, 11a, b), which is absent in type-I (Fig. 10a, b) and type-III (Fig. 12a, b) MJOs. This persistent convection over the WNP enhances westerly monsoon flows, thus upward latent heat flux, over the SCS and equatorial western Pacific (Fig. 11a, b) and inhibits the formation of robust and coherent positive SST anomalies ahead of Indian Ocean MJO convection (Fig. 9e, f). On the other hand, the lack of persistent convection over the WNP in type-I and type-III MJOs allows the tilted dry phase to generate robust positive SST anomalies ahead of Indian Ocean MJO convection (Fig. 9a, b, i, j). The persistent convection over the WNP also delays the northeastward migration of the dry phase and the development of Kelvin-wave-like responses in the equatorial Pacific region (Fig. 13g, h), thus inhibiting the formation of robust Pacific basin-wide overturning circulations. Present study reemphasizes the important role of enhanced boundary convergence ahead of MJO convection on its smooth eastward propagation (Wang and Li 1994; Hendon and Salby 1994; Jones and Weare 1996). It is expected that MJO convection in Indian Ocean will emanate a low sea level pressure tongue to its east as a Kelvin-wave response (e.g., the classic schematics of Madden and Julian 1972). The boundary-layer convergence driven by the Kelvin wave will precondition the atmosphere by transporting near surface moist air upward, thus leading the eastward propagation of the MJO convection. This is largely the case for type-I and type-III MJOs (Fig. 13). Present study discovers a new scenario, in which type-II MJO convection over eastern Indian Ocean fails to 
develop a robust low sea level pressure tongue in the equatorial Pacific, likely due to the interference of a persistent convection over the WNP.

Finally, the vertical moisture structures and budgets around the MC in association with three MJO types have been analyzed (Fig. 14). For both type-I and III MJOs, when their convection reaches western MC, positive boundarylayer moisture anomalies appear over the $\mathrm{MC}$ and western Pacific (Fig. 14a, c). Although weak negative moisture anomalies still present in the troposphere, column-integrated moisture tendencies are all positive over the MC and western Pacific, which apparently favor Indian Ocean MJO convection moving over the $\mathrm{MC}$ and entering western Pacific (e.g., DeMott et al. 2014; Feng et al. 2015). On the other hand, western Pacific troposphere for type-II MJO is still very dry with negative column-integrated moisture tendency (Fig. 14b), which indicates that when the type-II MJO convection is decaying over the MC due to the hostile environment there, western Pacific is still not ready for the MJO to move in.

In addition to the positive SST anomalies (Hirata et al. 2013) and orographically-induced surface convergence (Hsu and Lee 2005), our study further emphasizes the importance of a robust kelvin-wave response over the equatorial Pacific and a Pacific basin-wide overturning circulation on the propagation of Indian Ocean MJO over the MC. During boreal summer, the strong dryness over western Pacific in association with type-II MJO actually hinders the eastward propagation of Indian Ocean MJO convection rather than favoring its eastward propagation over the $\mathrm{MC}$ as suggested by Kim et al. (2014). Further studies are needed to resolve these contradictory results in terms of the role of strong dryness over the MC and western Pacific on the eastward propagation of the MJO.

Acknowledgements This work is supported by NOAA NWS grant (NA16NWS4680019), the China National Basic Research (973) Program (2015CB453203), NOAA CPO ESS grant (NA15OAR4310175), and the China Meteorological Special Project (GYHY201406022). T. Shinoda is also supported by NSF grant AGS-1347132. This paper is SOEST contribution number 10263 and IPRC contribution number 1293.

Open Access This article is distributed under the terms of the Creative Commons Attribution 4.0 International License (http://creativecommons.org/licenses/by/4.0/), which permits unrestricted use, distribution, and reproduction in any medium, provided you give appropriate credit to the original author(s) and the source, provide a link to the Creative Commons license, and indicate if changes were made.

\section{References}

Adames AF, Wallace JM, Monteiro JM (2016) Seasonality of the structure and propagation characteristics of the MJO. J Atmos Sci 73:3511-3526

Barrett BS, Leslie LM (2009) Links between tropical cyclone activity and the Madden-Julian oscillation phase in the North Atlantic and northeast Pacific basins. Mon Wea Rev 137:727-744

Brown TJ, Hall BL (1999) The use of t values in climatological composite analyses. J Clim 12:2941-2944

DeMott CA, Stan C, Randall DA, Branson MD (2014) Intra-seasonal variability in coupled GCMs: the roles of ocean feedbacks and model physics. J Clim 27:4970-4995

Duchon CE (1979) Lanczos filtering in one and two dimensions. J Appl Meteorol 18:1016-1022

Feng J, Li T, Zhu WJ (2015) Propagating and non-propagating MJO events over Maritime Continent. J Clim 28:8430-8449

Fu X, Wang B (2004) The boreal-summer intra-seasonal oscillations simulated in a hybrid coupled atmosphere-ocean model. Mon Wea Rev 132:2628-2649

Fu X, Lee J-Y, Hsu P-C, Taniguchi H, Wang B, Wang WQ, Weaver S (2013) Multi-model MJO forecasting during DYNAMO/CINDY period. Clim Dyn 41:1067-1081

Hendon HH, Salby ML (1994) The life cycle of the Madden-Julian Oscillation. J Atmos Sci 51:2225-2237

Hirata FE, Webster PJ, Toma VE, 2013: Distinct manifestations of austral summer tropical intra-seasonal oscillations. Geophys Res Lett 40:3337-3341. doi:10.1002/grl.50623

Hsu HH, Lee MY (2005) Topographic effects on the eastward propagation and initiation of the Madden-Julian Oscillation. J Clim 18:795-809

Huffman GJ et al. (2007) The TRMM multisatellite precipitation analysis (TMPA): quasi-global, multiyear, combined-sensor precipitation estimates at fine scales. J Hydrometeorol 8:38-55

Inness PM, Slingo JM (2006) The interaction of the Madden-Julian Oscillation with the Maritime Continent in a GCM. Q J R Meteorol Soc 132:1645-1667

Johnson HR, Rickenbach TM, Rutledge SA, Ciesielski PE, Schubert WH (1999) Trimodal characteristics of tropical convection. J Clim 12:2397-2418

Jones C, Weare BC (1996) The role of low-level moisture convergence and ocean latent heat fluxes in the Madden-Julian Oscillation: An observational analysis using ISCCP data and ECMWF analyses. J Clim 9:3086-3104

Julian PR, Madden RA (1981) Comments on a paper by T. Yasunari, A quasi-stationary appearance of 30-40 day period in the cloudiness fluctuation during the summer monsoon over India. J Meteorol Soc Jpn 59:435-437

Kikuchi K, Wang B, Kajikawa Y (2012) Bimodal representation of the tropical intraseasonal oscillation. Clim Dyn 38(9-10):1989-2000

Kiladis NG, Dias J, Straub KH, Wheeler MC, Tullich SN, Kikuchi K, Weickmann KM, Ventrice MJ (2014) A comparison of OLR and circulation-based indices for tracking the MJO. Mon Wea Rev 142:1697-1715

Kim DH, Kug J-S, Sobel AH (2014) Propagating versus non-propagating Madden-Julian oscillation events. J Clim 27:111-125

Klotzbach PJ (2010) On the Madden-Julian oscillation-Atlantic hurricane relationship. J Clim 23:282-293

Knutson TR, Weickmann KM (1987) 30-60 day atmospheric oscillations: composite life cycles of convection and circulation anomalies. Mon Wea Rev 115:1407-1436

Knutson TR, Weickmann KM, Kutzbach JE (1986) Global-scale intraseasonal oscillations of outgoing longwave radiation and $250 \mathrm{mb}$ zonal wind during Northern Hemisphere summer. Mon Wea Rev 114:605-623 
Kodama Y-M, Tokuda M, Murata F (2006) Convective activity over the Indonesian Maritime Continent during CPEA-I as evaluated by lightning activity and Q1 and Q2 profiles. J Meteorol Soc Jpn 84A:133-149. doi:10.2151/jmsj.84A.133

Krishnamurti TN, Bhalme H (1976) Oscillation of a monsoon system. J Atmos Sci 33:1937-1954

Krishnamurti TN, Jayakumar PK, Sheng J, Surgi N, Kumar A (1985) Divergent circulations on the 30 to 50 day time scale. J Atmos Sci 42:364-375

Krishnamurti TN, Oosterhof DK, Mehta AV (1988) Air-sea interaction on the time scale of 30 to 50 days. J Atmos Sci 45:1304-1322

Lau K-M, Chan PH (1985) Aspects of the 40-50 day oscillation during the northern winter as inferred from outgoing longwave radiation. Mon Wea Rev 113:1889-1909

Lau K-M, Chan PH (1986) Aspects of the 40-50 day oscillation during the Northern Summer as inferred from outgoing longwave radiation. Mon Wea Rev 114:1354-1367

Lawrence DM, Webster PJ (2002) The boreal summer intra-seasonal oscillation: relationship between northward and eastward movement of convection. J Atmos Sci 59:1593-1606

Lee J-Y, Wang B, Wheeler MC, Fu X, Waliser DE, Kang I-S (2013) Real-time multi-variate indices for the boreal summer intraseasonal oscillation over the Asian summer monsoon region. Clim Dyn 40:493-509

Liebmann B, Smith CA (1996) Description of a complete (interpolated) outgoing longwave radiation. Bull Am Meteorol Soc $77: 1275-1277$

Liebmann B, Hendon HH, Glick JD (1994) The relationship between tropical cyclones of the western Pacific and Indian Oceans and the phase of the MJO. J Meteorol Soc Jpn 72:401-412

Lorenc AC (1984) The evolution of planetary-scale 200-mb divergent flow during the FGGE year. Quart J R Meteorol Soc 110:427-441

Madden RA, Julian PR (1971) Detection of a 40-50-day oscillation in the zonal wind in the tropical Pacific. J Atmos Sci 28:702-708

Madden RA, Julian PR (1972) Description of global-scale circulation cells in the tropics with a $40-50$ day period. J Atmos Sci 29:1109-1123

Maloney E, Hartmann D (2000) Modulation of eastern North Pacific hurricanes by the Madden-Julian oscillation. J Clim 13:1451-1460

Matthews AJ (2000) Propagation mechanisms for the Madden-Julian Oscillation. Quart J R Meteorol Soc 126:2637-2652

Matthews AJ (2008) Primary and successive events in the MaddenJulian oscillation. Quart J R Meteorol Soc 134:439-453

Murakami M (1976) Analysis of summer monsoon fluctuations over India. J Meteorol Soc Jpn 54:15-31

Murakami M (1980) Empirical orthogonal function analysis of satellite-observed outgoing longwave radiation during summer. Mon Wea Rev 108:205-222

Nitta T, Mizuno T, Takahashi K (1992) Multi-scale convective systems during the initial phase of the 1986/1987 El Nino. J Meteorol Soc Jpn 70:447-466

Oh J-H, Kim B-M, Kim K-Y, Song H-J, Lim G-H (2013) The impact of the diurnal cycle on the MJO over the Maritime Continent. Clim Dyn 40:893-911
Roundy PE (2014) Some aspects of Western Hemisphere circulation and the Madden-Julian oscillation. J Atmos Sci 71:2027-2039

Roundy PE, Frank WM (2004) Effects of low-frequency wave interactions on intra-seasonal oscillations. J Atmos Sci 61:3025-3040

Rydbeck AV, Maloney ED, Xie S-P, Hafner J, Shaman J (2013) Remote forcing versus local feedback of east Pacific intra-seasonal variability during boreal summer. J Clim 26:3575-3596

Saha $S$ et al (2010) The NCEP climate forecast system reanalysis. Bull Am Meteorol Soc 91:1015-1057

Schreck CJ, Molinari J (2011) Tropical-cyclogenesis associated with Kelvin waves and the Madden-Julian oscillation. Mon Wea Rev 139:2723-2734

Stachnik JP, Waliser DE, Majda AJ (2015) Precursor environmental conditions associated with the termination of Madden-Julian Oscillation events. J Atmos Sci 72:1908-1931

Ventrice MJ, Thorncroft CD, Roundy PE (2011) The Madden-Julian Oscillation's influence on African easterly waves and downstream tropical cyclogenesis. Mon Wea Rev 139:2704-2722

Vitart F, Woolnough S, Balmaseda MA, Tompkins AM (2007) Monthly forecast of the Madden-Julian oscillation using a coupled GCM. Mon Wea Rev 135:2700-2715

Wang B, Li T (1994) Convective interaction with boundary-layer dynamics in the development of a tropical intra-seasonal system. J Atmos Sci 51:1386-1400

Wang B, Rui H (1990) Synoptic climatology of transient tropical intraseasonal convective anomalies: 1975-1985. Meteorol Atmos Phys 44:43-61

Wang B, Xie XS (1997) A model for the boreal summer intraseasonal oscillation. J Atmos Sci 53:449-467

Wang B, Webster PJ, Teng H (2005) Antecedents and self-induction of active-break south Asian monsoon unraveled by satellites. Geophys Res Lett 32:L04704. doi:10.1029/2004GL020996

Wang B, Webster P, Kikuchi K, Yasunari T, Qi YJ (2006) Boreal summer quasi-monthly oscillation in the global tropics. Clim Dyn 27:661-675. doi:10.1007/s00382-006-0163-3

Wentz FJ, Gentemann CL, Smith DK, Chelton DB (2000) Satellite measurements of sea surface temperature through clouds. Science 288:847-850. doi:10.1126/science

Yanai M, Esbensen S, Chu J-H (1973) Determination of bulk properties of tropical cloud clusters from large-scale heat and moisture budgets. J Atmos Sci 30:611-627

Yasunari T (1979) Cloudiness fluctuation associated with the northern hemisphere summer monsoon. J Meteorol Soc Jpn 57:227-242

Yasunari T (1980) A quasi-stationary appearance of 30 to 40 day period in the cloudiness fluctuations during the summer monsoon over India. J Meteorol Soc Jpn 58:225-229

Zhang CD, Hendon HH (1997) Propagating and standing components of the intra-seasonal oscillation in tropical convection. J Atmos Sci 54:741-752

Zhu B, Wang B (1993) The 30-60 day convection seesaw between the tropical Indian and western Pacific Oceans. J Atmos Sci 50:184-199 